Vietnam Academy of Science and Technology
(VAST) Vietnam Journal of Earth Sciences
http://www.vjs.ac.vn/index.php/jse

\title{
Some study results of Cam Ranh - Binh Thuan mud eruption strip
}

\author{
Bui Van Thom ${ }^{*}$, Phan Trong Trinh ${ }^{1}$, Ngo Tuan $\mathrm{Tu}^{2}$, Nguyen Anh Duong ${ }^{1}$, Nguyen Dang \\ Manh $^{1}$ \\ ${ }^{l}$ Institute of Geological Sciences, Vietnam Academy Science and Technology \\ ${ }^{2}$ Division of planning and investigation of water resources in central region
}

Received 25 April 2016. Accepted 11 June 2016

\begin{abstract}
Most of the mud eruption locations are distributed in a stretching strip, running in NE-SW direction from Cam Ranh - Ninh Thuan - Binh Thuan NE-SW tectonic fault zone and coinciding with a tectonically crushed zone. The erupted mud consists of sand, mud, clay. The clay contains alkaline montmorillonite, formed following chemical weathering and re-sedimentation processes from rocks containing alkaline minerals in a semi-arid climate area, located in a low terrain or a tectonic subsiding zone with a large fluctuation in groundwater level. The mud eruption has a close relation to factors (of) climate, topography, geomorphology, hydrogeology, , petrography and tectonic activities in the area. Among these, tectonic factors are the most important for they create not only soil and rock crushed zone, paving favorable conditions for strong weathering process at depth, but also to form canals to bring hot groundwater and minerals from certain depths upward, and by the effects of pressurized groundwater and partly due to the expansion in volume of bentonite clay pushing the muddy clay material through the tectonic cracks to the surface of the current terrain. The mud eruption process is not deep; but it may occur from a shallow level, about 4$18 \mathrm{~m}$ below, under the impact of the above elements.
\end{abstract}

Keywords: Mud eruption; bentonite clay; tectonic fault zone; Ninh Thuan mud eruption.

(C)2016 Vietnam Academy of Science and Technology

\section{Introduction}

In recent years, a series of ash, gas and mud eruptions occurred in Vietnam. These include ash eruption on Tro island, South of Phu Quy island in Binh Thuan; gas and ash eruption in the Chu Prong district (Gia Lai); gas and mud eruption in the Tien Hai district, (Thai Binh); mud eruption in the Ninh Hoa district (Khanh Hoa), Krong Pa district (Gia Lai), Nha Me and Vinh Hao in the Tuy Phong

*Corresponding author, Email: buivanthom @ gmail.com district of Binh Thuan province, Nhi Ha of Thuan Nam district (Ninh Thuan), and Cam Thinh Dong of Cam Ranh city. As recently as in 2011, in the Suoi Da village of Loi Hai commune, Thuan Bac district, Ninh Thuan province a series of mud eruptions occurred, which created floating docks up to about 0.5 $\mathrm{m}$ high, and pit mouths about $1.0-1.5 \mathrm{~m}$ wide. The mud was loose that spilled all over around making some fields impossible to be cultivated, burying the cattle to death. The mud eruption phenomenon caused social 
anxiety and even presented the life-threatening danger to both native people and livestock. In the rainy season, the mud eruption occurs even more often and stronger, so that the local authorities have to ban the land farming and issue warning signboards in the dangerous areas.

Regardless of the lurking dangers caused by mud eruptions, the erupted muds also present significant economic benefits. The fact is that at many mud-eruption sites such as Cam Thinh Dong, Vinh Hao, Nha Me, the mud is exploited and used for mud bath healing purposes. Particularly, in the area of Nha Me, beside the mineral mud bath service, mud is also exploited as an additive for the agriculture, industry and health purposes by Minh $\mathrm{Ha}$ and Minh Tam Company (http://www.mhc.vn/).

At present, there are only a few studies of the mud eruption band, but only studies conducted for separate eruption sites without showing the interrelationship among the eruption sites. For example, erupted mud in the Nha Me, Tuy Thinh and Vinh Hao villages was determined for chemical compositions with aim to exploring and exploiting useful minerals (Ho Vuong Binh, 1986); while at Loi Hai and Cam Thinh Dong eruption sites, mud was analyzed and evaluated for purpose of using mineralized mud in healing therapy (Nguyen Duc Thai, Ngo Tuan $\mathrm{Tu}, 2011)$. Besides, on several Internet websites, some geo-scientific have offered very different explanations on causes of mud eruption in the Suoi Da village, Loi Hai commune. Three major opinions may be summarized as follows. Firstly, mud eruption is caused by external processes or the expansion of alkaline bentonite clay (VnExpress, 21/03/2011) and kienthuc.net.vn news-paper, 28/03/2011). Secondly, the eruption may be related to tectonic fault activities (Nguyen Hong Phuong, Dan Tri newspaper, 29/03/2011, and others including Cao Dinh
Trieu, Phan Trong Trinh (personal communication). Lastly, to the mud eruption is caused by shallow crustal tectonic fault activities along with the combined effect of surface precipitation flow, pressurized groundwater flow, and weak ground foundation (Nguyen Duc Thai, Nguyen Ngoc Tu and others, 2011).

Therefore, the purpose of this study, along with currently available literature, is to clarify the causes, mechanisms and the relationship between mud eruption and related-tectonic and geological factors along the Cam Ranh Ninh Thuan - Binh Thuan strip. The research should help understand more clearly the nature of the mud eruption in order to provide the local decision-makers with reasonable solutions for hazard mitigation, on the one hand, and effective use of the mud materials, on the other.

\section{Documentation and study methods}

\subsection{Documentation}

Documentation includes reports of mud eruption in Loi Hai by the Division of Planning and Investigation of Water Resources in Central region; report on evaluating the prospect and possibility of using alkaline bentonite in Thuan Hai (Ho Vuong Binh, 1986), geological maps at scale $1: 200,000$ (Nguyen Duc Thang and others, 1988) and 1:50,000 (P. Stepanek, Ho Trong Ty, 1986); Landsat multispectral satellite imagery, resolution from 2.5 to $30 \mathrm{~m}$; field survey, drilling and digging records, chemical compositions of erupted muds reported by project coded VAST05.03/14-15. The above documents have contributed significantly to determine the causes and mechanisms of mud eruption in Ninh Thuan - Binh Thuan, while materials of the mud diapir in the East Vietnam Sea are considered for comparison (Phan Trong Trinh, 2011, 2012).

\subsection{Study methods}


Remote sensing image analysis: analysis of high resolution remote sensing images help identify the location and distribution rule of erupted mud vents. Because the mud materials, often deposited with clay minerals upon eruption, are evaporated and dried, so the image normally appears in white color, circleshaped or stripped. Because vents of mud mounds usually contain water, the image appears in black color; therefore, it is possible to identify and localize the pits, mounds of erupted mud on the images.

Method of synthetic analysis Mud eruption materials and especially materials containing alkaline bentonite clay must be formed in a high alkaline environment, $\mathrm{pH} \approx$ 9-11 in an oxidation zone. This means that it must lie below the annual underground water level, which should be the lower part of the secondary accumulated section in a deep depression setting related to a tectonic fault zone containing soda-carbonate with high $\mathrm{pH}$. The elements related to mud eruption may include topography, hydrology, lithology, tectonics and hydrology. Therefore, analysis and evaluation of the impact of these elements are necessary to determine the origin, mechanism of forming mud materials as well as the dynamics of mud eruption development.

Method of geochemical-mineralogical analysis: chemical compositions of mud materials and the surrounding rocks, weathering layers, especially the clay containing alkaline bentonite often associated with the chemical weathering process of alkaline rocks, and the host rocks are conducted to clarify the compositional characteristics of mud materials as well as the geochemical forming conditions of alkaline clay materials, in particular, and weathered cover, in general.

Geophysical method: in order to obtain accurate conclusions on the deeper parts, it is necessary to drill, dig, and especially to conduct geophysical measurement. Deep electrical image and shallow seismic image measurements were conducted with aim to identify deep geological structures.

\section{Results}

\subsection{Distribution characteristics of mud}

Within the study scope from Cam Ranh Ninh Thuan to Binh Thuan with a length of about $100 \mathrm{~km}, 6$ mud eruption locations were determined (Figure 1) showing the following characteristics:

Mud eruption in Ta Luong, Cam Phuoc Dong Commune, Cam Ranh City, at $109^{\circ}$ $06^{\circ} 08^{\prime \prime} \mathrm{E}$ and $11^{\circ} 5652^{\prime \prime} \mathrm{N}$, first appeared in November 1999, forming a strip running in NE-SW direction, including 12 mud mounds, rising about $0.1 \mathrm{~m}$ above the surface, and covering an area from 10 to $300 \mathrm{~m}^{2}$, and about $0.5 \mathrm{~m}$ to $4.0 \mathrm{~m}$ thick although the thickest cover reaching $8 \mathrm{~m}$ at some parts. The mud continuously spills out from the channels, stronger in the rainy season (Figure 2, 3). The mud is grayish yellow or light green, very fine-grained and highly hydrous, appearing in the form of emulsion having high adhesion and flexibility. The clayish mud component accounts for $30 \%$ (Nguyen Duc Thai and others, 2011). A geological cross-section running through the erupted mud area (Figure 4) shows that the mud materials at depth between 4 and $8 \mathrm{~m}$ are clay lenses containing montmorillonite. While the weathering zone comprises rock chips, gravel, sand and clay produced from erupted rocks including rhyolite, felsic magmas, dacite, tuffogenic sandstone, alternating conglomerates. The conglomerate and gravel are composed of biotite-hornblende granodiorite belonging to the calc-alkaline series with medium alkalinity $(\mathrm{P}$. Stepanek, Ho Trong Ty, 1986; Nguyen Duc Thang and others, 1988). The native rock is shattered and fractured, forming a deformed zone with width of $20 \mathrm{~cm}$, in the direction of NW-SE (3300), towards NE with slope angle of 750 (Figure 5) and coincides with the mud eruption location. About $3 \mathrm{~km}$ from the mud eruption location to the west, there appears an exposing hot mineral water at the pond side of the residential area (Figure 2). 
B.V. Thom, et al./Vietnam Journal of Earth Sciences 38 (2016)

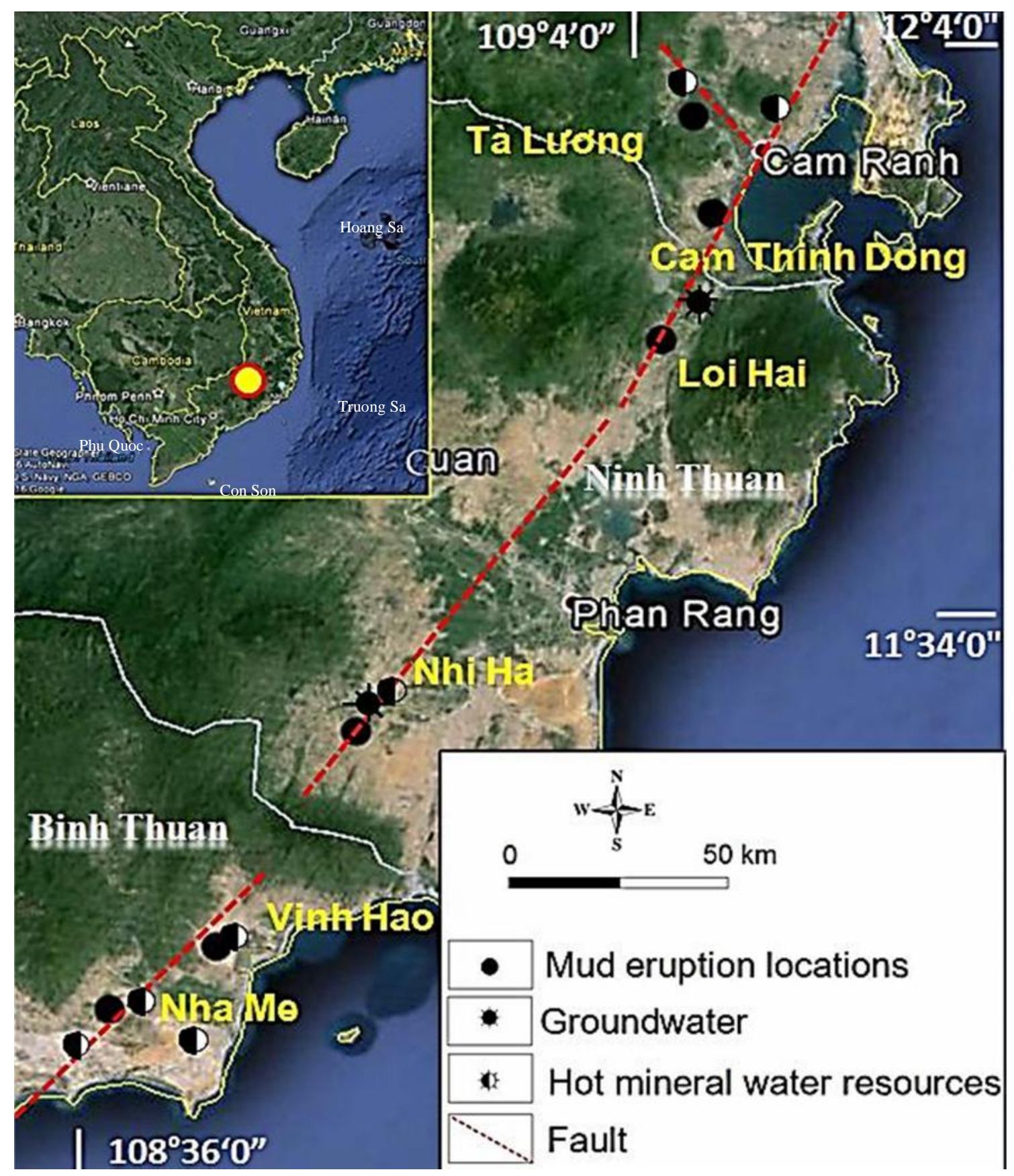

Figure 1. Distribution of mud eruption locations at Cam Ranh - Binh Thuan 


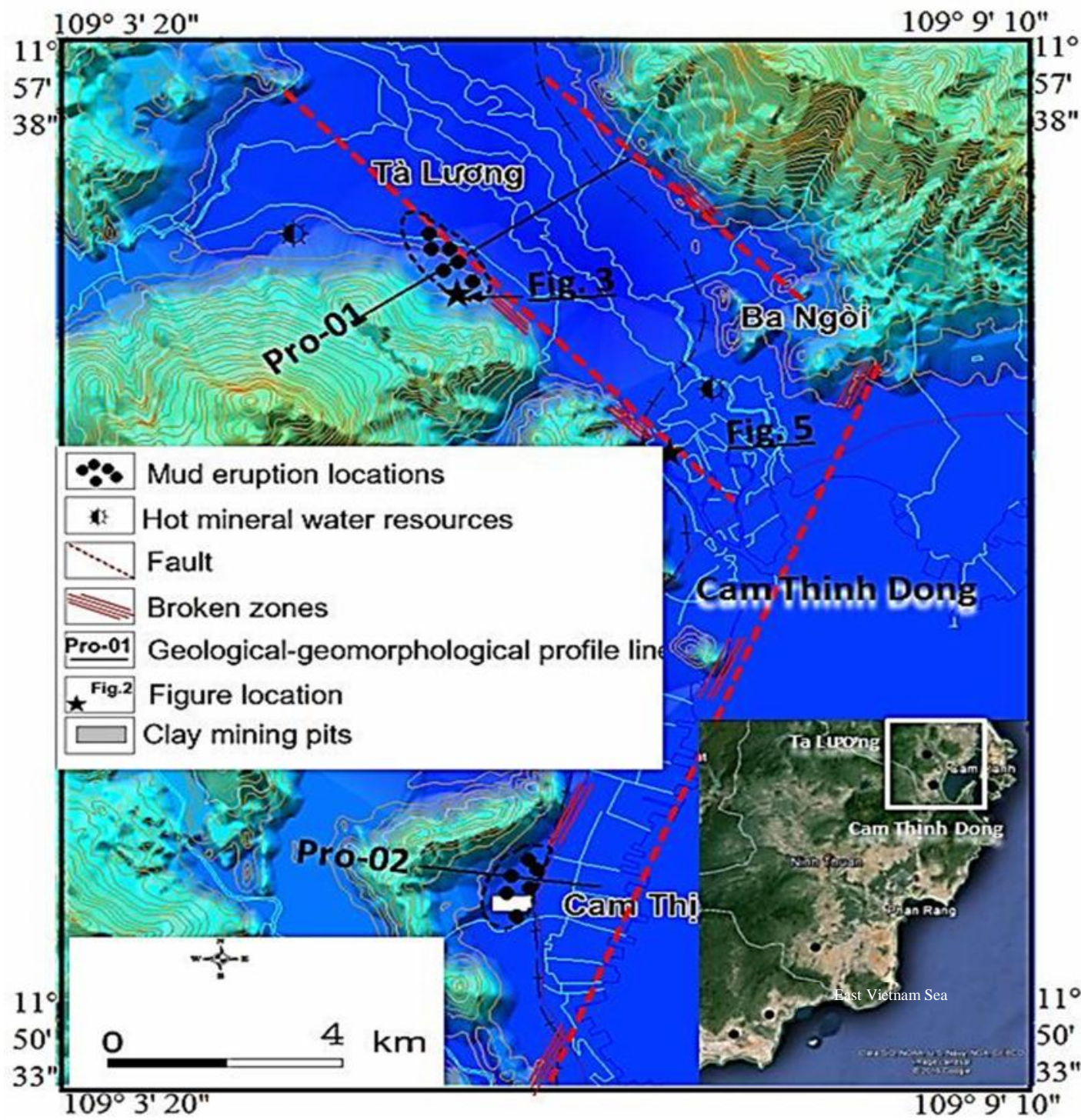

Figure 2. Map of current mud eruption status at Ta Luong and Cam Thinh Dong

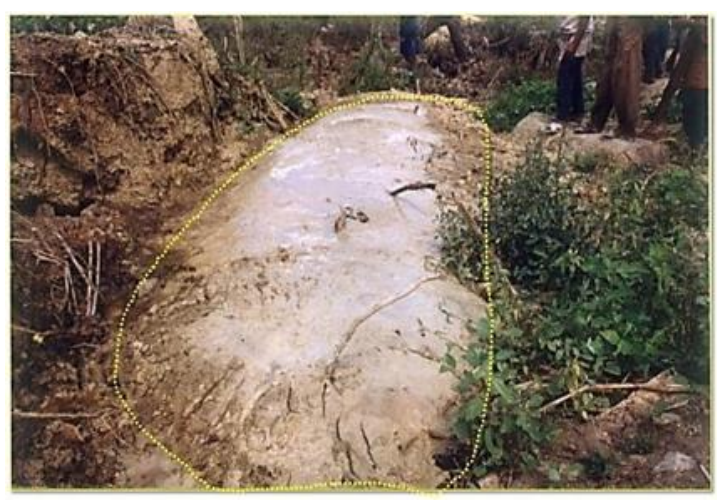

Figure 3. One of mud eruption location at Ta Luong
Mud eruption in Cam Thinh Dong, Cam Ranh City, at $109^{\circ} 06^{\prime} 31^{\prime \prime} \mathrm{E}$ and $11^{\circ} 53^{\prime} 15^{\prime \prime} \mathrm{N}$, appeared at 22 mud mounds, rising about 0.1 to $0.5 \mathrm{~m}$ above the ground, the average depth of each mud mound is from 0.7 to $6.5 \mathrm{~m}$. All the mud mounds are distributed in bands of NE - SW direction, $600 \mathrm{~m}$ long and 40 to 120 $\mathrm{m}$ wide on a relatively flat terrain (Figure 2). The clayish mud materials are light gray, grayish-light green, soft and hydrous, containing a significant number of sand and gravel. Watery clayish mud is leaked on the vents of mud mounds. The smooth level of 
B.V. Thom, et al./Vietnam Journal of Earth Sciences 38 (2016)

mud is low in the content of silt, bentoniterich clay accounts for $41.3 \%$ while sand and gravel account for 58.7\%). A geological cross-section through a mud eruption site (Figure 6) shows that the montmorillonitebearing clay occurs at depth of 4 to $6.5 \mathrm{~m}$, under the weathering layer of sandstone and volcanic tuff of Nha Trang formation. About
$300 \mathrm{~m} \mathrm{NE}$ of the mud eruption location, there encounters 0.5 to $0.7 \mathrm{~m}$ crushed zone running in NE-SW $\left(30^{\circ}\right)$ direction, inclining towards the SW direction with a sloping angle of 850 . About $500 \mathrm{~m} \mathrm{NE}$ of the mud eruption location, there exposes Ba Ngoi hot mineral water with $\mathrm{H} 2 \mathrm{~S}$ emission (Vo Cong Nghiep and others, 1998).

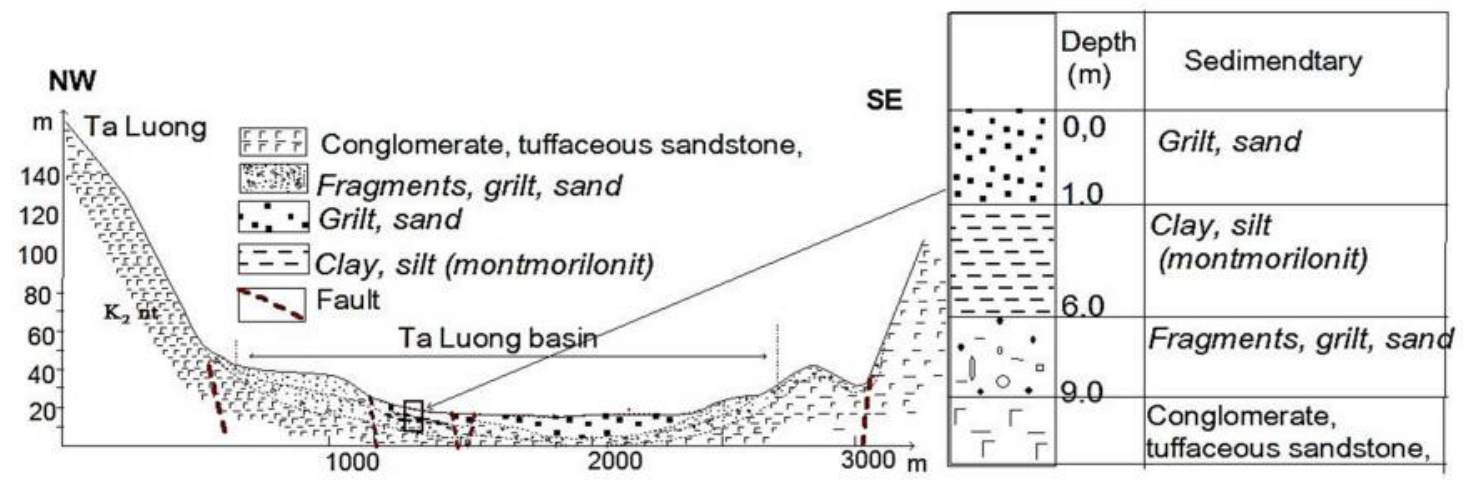

Figure 4. Geological and geomorphological profile at Ta Luong

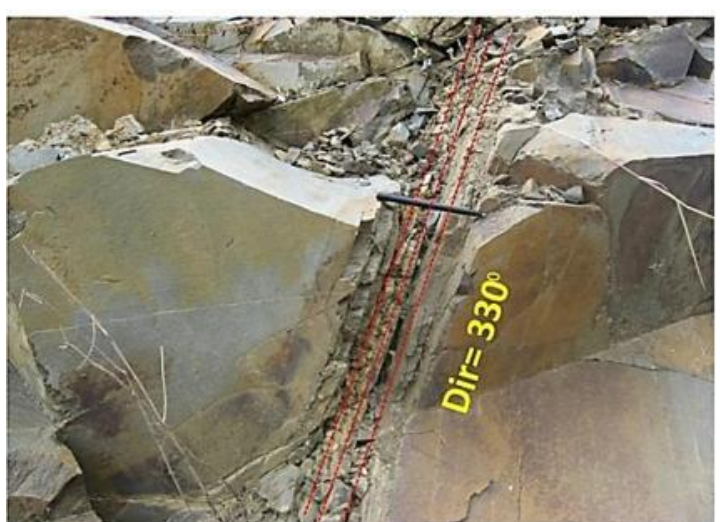

Figure 5. Broken zones in the rock at Ta Luong

Mud eruption in the Suoi Da village, Loi Hai commune, Thuan Bac district, Ninh Thuan province at $109^{\circ} 3^{\prime} 48^{\prime \prime} \mathrm{E}, 11^{\circ} 46^{\prime} 15^{\prime \prime} \mathrm{N}$, occurs at 5 mud mounds rising about $0.5 \mathrm{~m}$ in some paddy fields (Figure 7,8) with depth about $6 \mathrm{~m}$, distributed in 2 strips of NE-SW and sub-longitude direction. The mud comprises mainly of clay, sand, gravel and mud, appearing in light gray or light blue color. Regular water leakage is observed on the vents of mud mounds. Clay and mud are watery, sticky, soft, cool with high adhesion and flexibility. An analytical result of a muddy clay sample shows montmorillonitebearing clay with grain size $<0.063 \mathrm{~mm}$ accounting for $71 \%$, and clay and mud of grain size $>0.063 \mathrm{~mm}$ accounting for $29 \%$. (Table 1). The main mineral composition of grain size $>0.063 \mathrm{~mm}$ (equivalent to silt, sand, gravel) is quartz, accounting for $20-22 \%$, feldspar of $40 \%$, and residual clay minerals of $15-20 \%$. Thus, the montmorillonite-bearing clay is low, accounting for only 20-30\%. In order to effectively exploit, the clay must process in-situ for montmorillonite enrichment.

Geological formations are clearly exposed in cross-sections in some pits and outcrops along the Suoi Da stream bank, including (Figure 9): top layer (1), 0 to $0.3 \mathrm{~m}$ thick comprised of humus (soil); layer 2, from 0.3 to $1.7 \mathrm{~m}$ deep contains medium-grained yellow sand and patchy white patchy; layer 3 from 1.7 to $2.2 \mathrm{~m}$ is coarse-grained sand mixed with debris of host rock and mediumgrained consolidated rock; layer 4 from 2.2 to $6.0 \mathrm{~m}$ includes sand, silt, blue-gray and white clay containing montmorillonite; layer 5 , from $6.0 \mathrm{~m}$ or less is sand, chips and gravel mixed with host rock located directly on intrusive rocks of Dinh Quan complex $\left(\sigma-\gamma \sigma-\gamma \mathbf{J}_{3} d q\right)$. 
Vietnam Journal of Earth Sciences 36 (2016) 307-315

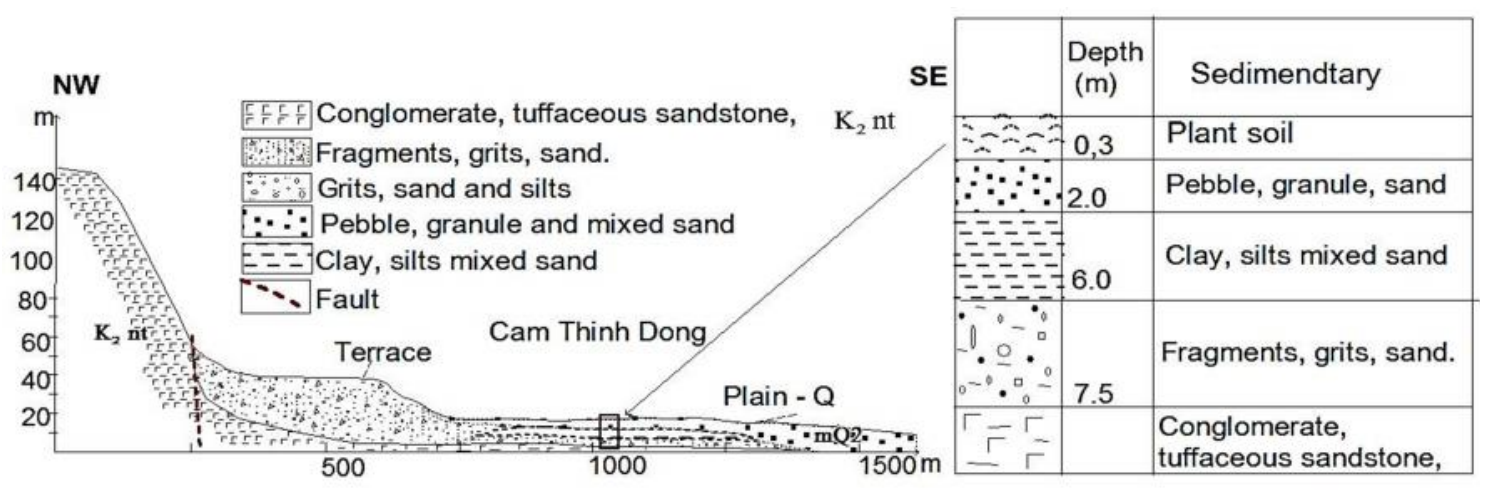

Figure 6. Geological and geomorphological Profile at Cam Thinh Dong

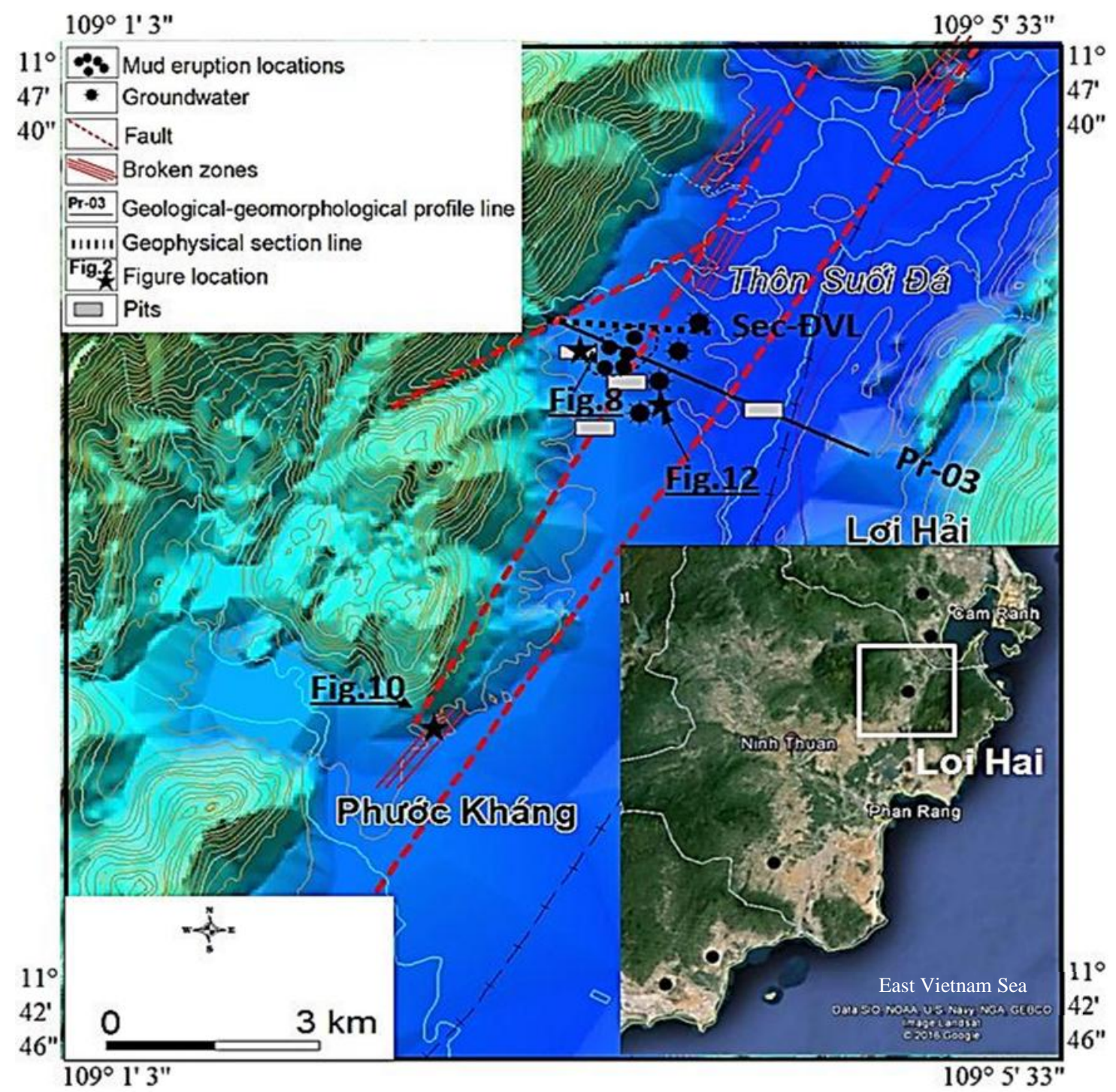

Figure 7. Map of current mud eruption status at Suoi Da village, Loi Hai commune 
Vietnam Journal of Earth Sciences 36 (2016) 307-315

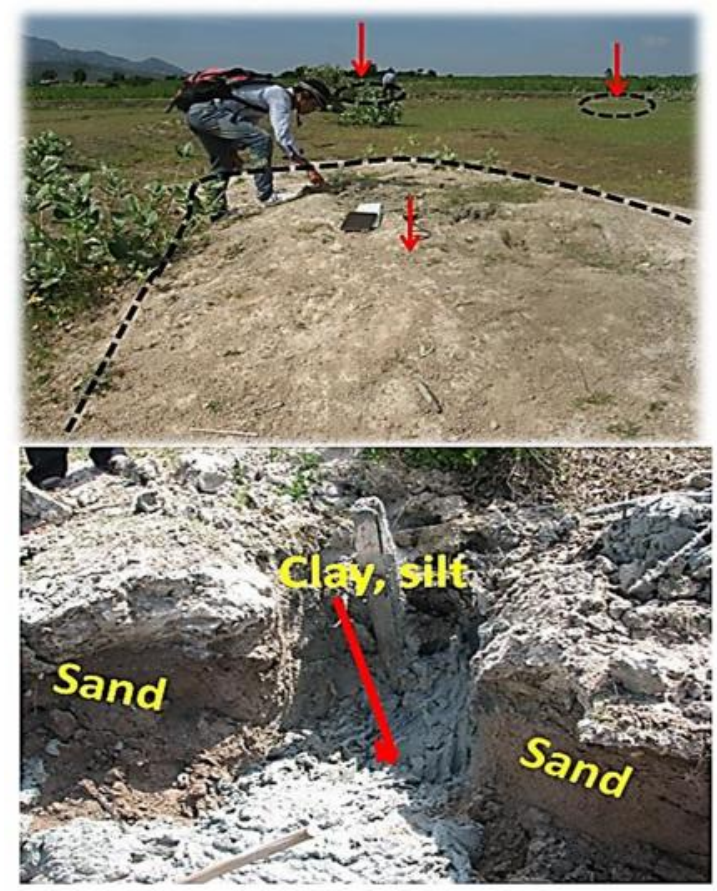

$\leftarrow$ Figure 8. One of mud eruption location at Suoi Da village, Loi Hai commune

Table 1. Mineral composition at clay level $<0,063 \mathrm{~mm}$ mud eruption location at Suoi Da village, Loi Hai commune, Thuan Bac district

\begin{tabular}{|c|c|c|c|}
\hline \multirow{2}{*}{ No } & \multirow{2}{*}{ Minerals } & \multicolumn{2}{|c|}{$\begin{array}{c}\text { Mineral composition } \\
\text { at clay level }<0,063 \mathrm{~mm}\end{array}$} \\
\hline & & BLH01 & BLH02 \\
\hline 1 & Montmorilonit & $30-40$ & $25-30$ \\
\hline 2 & Ilit & 15 & 12 \\
\hline 3 & Kaolinit & $5-10$ & $10-15$ \\
\hline 4 & Clorit & $4-5$ & 5 \\
\hline 5 & Feldspar & $4-5$ & $10-15$ \\
\hline 6 & Quartz & $10-15$ & $5-8$ \\
\hline 7 & Ferric hydroxide (gotit) & $6-8$ & $4-5$ \\
\hline 8 & Canxit $\mathrm{CaCO}_{3}$ & 4 & 5 \\
\hline 9 & Ankerit $(\mathrm{Mg}, \mathrm{Fe}) \mathrm{CO}_{3}$ & 4 & 5 \\
\hline
\end{tabular}

Note: The samples were analyzed at Geology Institute Vietnam Academy of Science and Technology - Column (3) and (4) were names of samples

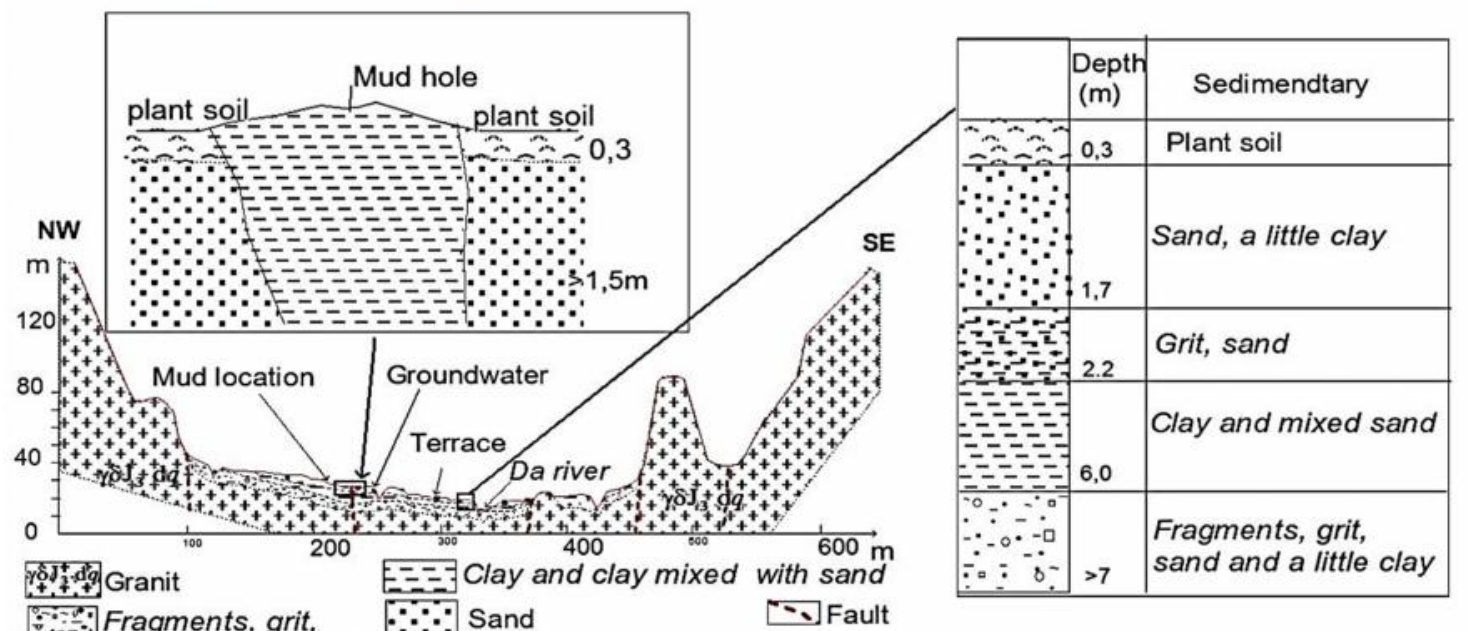

Figure 9. Geological and geomorphological profile at Loi Hai

About $70 \mathrm{~m} \mathrm{SE}$ from the mud eruption, there expose groundwater veins, distributed into a $100 \mathrm{~m}$ strip in the NE-SW direction, the flow of exposed veins is about 0.2-0.3 1/s (Figure 10). Towards the SE (in Phuoc Khang) in the outcropped walls of a water canal, exposed are strongly fractured and cracked granite host rock. The crushed zone is 1-2.5 $\mathrm{m}$ wide, running along the direction of
NE-SW (20-300), with direction towards SW making a vertical slope angle 85-880. In the zone found are sliding surfaces with clear scratches reflecting the existence of a tectonic fault zone, in which the azimuthal sliding surface with direction of slope $1100<860$, scratches on the sliding surface reflect a normal strike-slip motion. The analysis of a geological-electrical section (measuring 
electrical image) through the mud eruption location (nearly sub-latitude) identified a fault zone, extending along the direction of NE-SW cutting through the mud eruption location (Figure 11, 12).

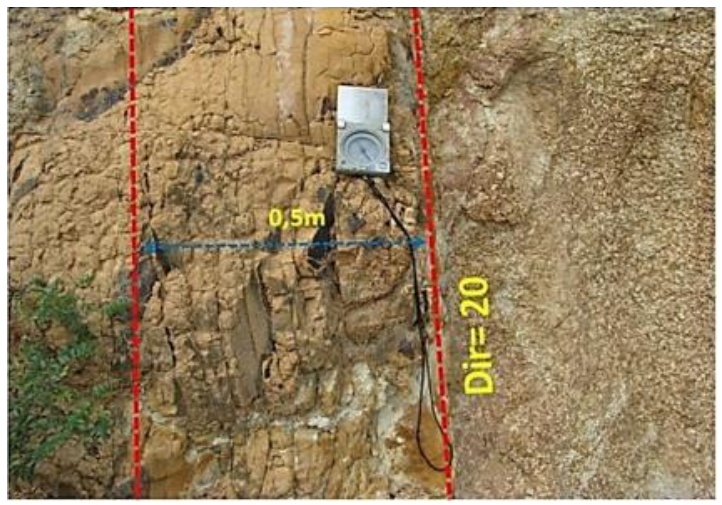

Figure 10. Broken zones in the rock at Phuoc Khang
The trace element composition of the Suoi Da mud was acquired and compared to that of Loc Ninh (Khanh Hoa), which has been studied, exploited and used for bathing of tourism - nursing, (Table 2, 3) showed that water close to vents of mud eruption is in light yellow color and strange smell and taste having $\mathrm{pH}=$ 8.81. The trace element contents are smaller relative to the standard level of bottled mineral water coded QCVN 6213:2004. As for flour criteria $(\mathrm{F}=5.98 \mathrm{mg} / \mathrm{l})$, the concentration is larger than the temporary standard of Vietnam on healing mineral water. For criteria of metasilic acid, it has relatively large content $\left(\mathrm{H} \leftarrow 2 \mathrm{SiO}_{3}=73.05 \mathrm{mg} / \mathrm{l}\right)$, according to the nominal criteria and standard of mineral water (Vo Cong Nghiep, 1998), classified in the silic-florur mineral water (Table 4). Thus, the mud material in the Suoi (stream) Da can be used as a material source of mineral mud.

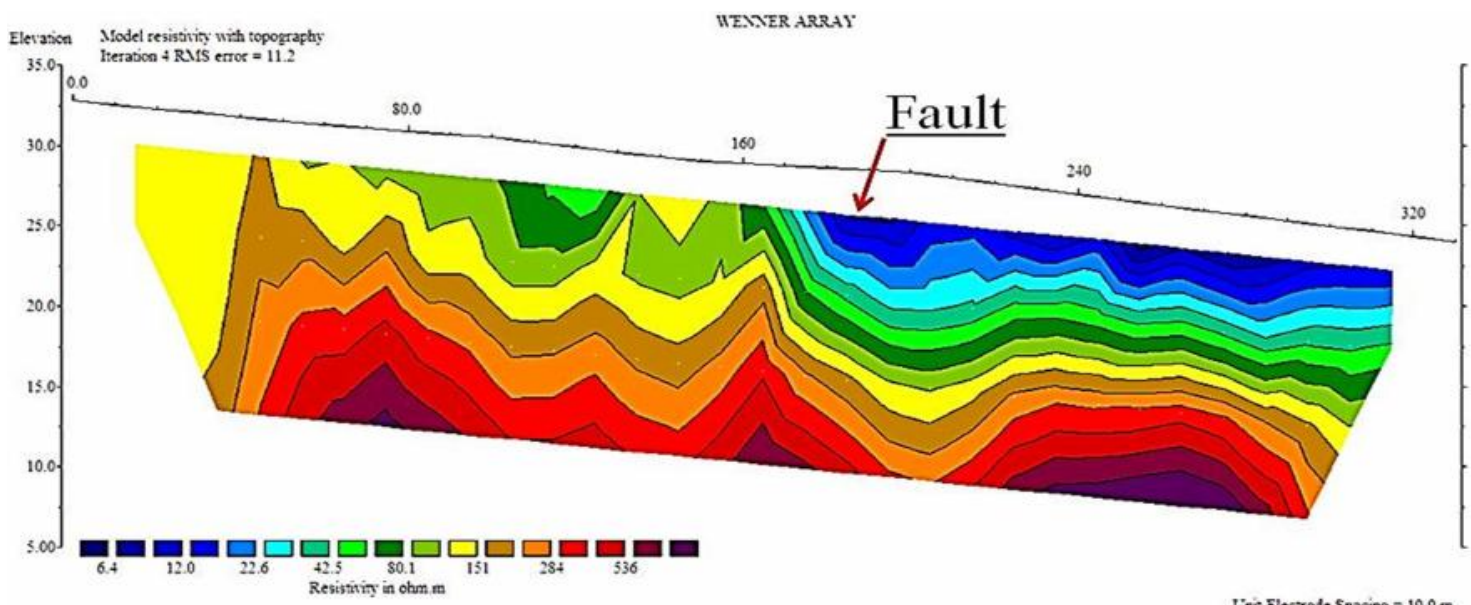

Figurre 11. Geophysical cross-sections through the mud eruption location at Loi Hai

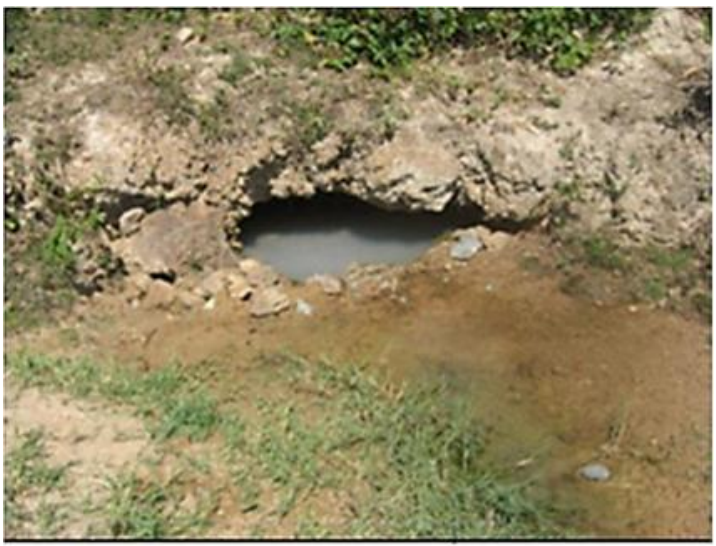

Figure 12. Groundwater appearance at Loi Hai
Mud eruption in Nhi $\mathrm{Ha}$, Nhi $\mathrm{Ha}$ commune, Thuan Nam District, Ninh Thuan Province, at $108^{\circ} 49^{\prime} 19^{\prime \prime} \mathrm{E}, 11^{\circ} 26^{\prime} 56^{\prime \prime} \mathrm{N}$, occupies an area up to 10,000 square meters, situated on the undulating plain, and composed of accumulated alluvial and proluvial mixture with a thin thickness of 0.2-0.5 meters, at some places bedrock can still be found. There are up to 50 mud mounds in the area, of 0.3$0.7 \mathrm{~m}$ high, spread in 5 strips, all running in NE-SW direction. On the mouth and around a mud mound, there appear more land cracks of several meters in length linking the mud mounds together (Figure 13, 14). 
Vietnam Journal of Earth Sciences 36 (2016) 307-315

Table 2. Summary analysis of clay in Suoi Da village, Loi Hai commune, Thuan Bac district

\begin{tabular}{|c|c|c|c|c|c|c|c|c|c|c|}
\hline \multicolumn{10}{|c|}{ Mud location of mud mound at Suoi Da (HB) } & \multirow{2}{*}{$\begin{array}{c}\text { Mud mine } \\
\text { at } \\
\text { Ninh Loc }\end{array}$} \\
\hline No & Citeria & Unit & HB. 01 & HB.02 & HB.03 & HB.04 & Maximum & Minimum & Average & \\
\hline (1) & (2) & (3) & (4) & (5) & (6) & (7) & (8) & (9) & (10) & (11) \\
\hline & I. Mud composition & & & & & & & & & \\
\hline 1 & $\mathrm{pH}$ & & 6.90 & 7.00 & 7.00 & 7.00 & 7.00 & 6.90 & 6.98 & 7.4 \\
\hline 2 & $\mathrm{SiO}_{2}$ & $\%$ & 74.48 & 81.44 & 75.34 & 78.14 & 81.44 & 75.34 & 77.35 & 65.53 \\
\hline 3 & $\mathrm{FeO}$ & $\%$ & 0.12 & 0.16 & 0.20 & 0.15 & 0.20 & 0.12 & 0.16 & 1.14 \\
\hline 4 & $\mathrm{Fe}_{2} \mathrm{O}_{3}$ & $\%$ & 2.24 & 0.880 & 1.84 & 1.44 & 2.24 & 1.44 & 1.60 & 4.7 \\
\hline 5 & $\mathrm{FeS}_{2}$ & $\%$ & $<0.01$ & $<0.01$ & $<0.01$ & $<0.01$ & $<0.01$ & $<0.01$ & $<0.01$ & $<0.01$ \\
\hline 6 & $\mathrm{Al}_{2} \mathrm{O}_{3}$ & $\%$ & 9.90 & 5.60 & 7.33 & 7.01 & 9.90 & 5.60 & 7.46 & 10.27 \\
\hline 7 & $\mathrm{MnO}$ & $\%$ & $<0.01$ & $<0.01$ & $<0.01$ & $<0.01$ & $<0.01$ & $<0.01$ & $<0.01$ & 0.03 \\
\hline 8 & Organic content & $\%$ & 1.86 & 1.800 & 1.62 & 1.74 & 1.86 & 1.62 & 1.76 & 0.55 \\
\hline & II. Mud solution com & ponents & & & & & & & & \\
\hline 1 & $\mathrm{HCO}_{3}^{-}$ & $\mathrm{mg} / \mathrm{l}$ & 67.10 & 54.90 & 57.95 & 61.00 & 67.10 & 54.90 & 60.24 & 305 \\
\hline 2 & $\mathrm{CO}_{3}{ }^{2-}$ & $\mathrm{mg} / \mathrm{l}$ & 0 & 0.00 & 0.00 & 0.00 & 0.00 & 0.00 & 0.00 & 0.00 \\
\hline 3 & $\mathrm{Cl}^{-}$ & $\mathrm{mg} / \mathrm{l}$ & 1.78 & 3.55 & 1.78 & 1.78 & 3.55 & 1.78 & 2.22 & 19.64 \\
\hline 4 & $\mathrm{SO}_{4}{ }^{2-}$ & $\mathrm{mg} / \mathrm{l}$ & 0.15 & 0.20 & 0.10 & 0.15 & 0.20 & 0.10 & 0.15 & 7.44 \\
\hline 5 & $\mathrm{NO}_{2}^{-}$ & $\mathrm{mg} / \mathrm{l}$ & $<0.01$ & $<0.01$ & $<0.01$ & $<0.01$ & $<0.01$ & $<0.01$ & $<0.01$ & $<0.01$ \\
\hline 6 & $\mathrm{NO}_{3}^{-}$ & $\mathrm{mg} / \mathrm{l}$ & $<0.01$ & $<0.01$ & $<0.01$ & $<0.01$ & $<0.01$ & $<0.01$ & $<0.01$ & $<0.01$ \\
\hline 7 & $\mathrm{Br}^{-}$ & $\mathrm{mg} / \mathrm{l}$ & $<0.01$ & $<0.01$ & $<0.01$ & $<0.01$ & $<0.01$ & $<0.01$ & $<0.01$ & $<0.01$ \\
\hline 8 & $\mathrm{I}^{-}$ & $\mathrm{mg} / \mathrm{l}$ & $<0.01$ & $<0.01$ & $<0.01$ & $<0.01$ & $<0.01$ & $<0.01$ & $<0.01$ & $<0.01$ \\
\hline 9 & $\mathrm{Ca}^{2+}$ & $\mathrm{mg} / \mathrm{l}$ & 4 & 3.00 & 4.00 & 5.00 & 5.00 & 3.00 & 4.00 & 2.8 \\
\hline 10 & $\mathrm{Mg}^{2+}$ & $\mathrm{mg} / \mathrm{l}$ & 0.61 & 1.220 & 1.82 & 1.22 & 1.82 & 0.61 & 1.22 & 1.705 \\
\hline 11 & $\mathrm{Fe}^{2+}$ & $\mathrm{mg} / \mathrm{l}$ & $<0.01$ & $<0.01$ & $<0.01$ & $<0.01$ & $<0.01$ & $<0.01$ & $<0.01$ & $<0.01$ \\
\hline 12 & $\mathrm{Fe}^{3+}$ & $\mathrm{mg} / \mathrm{l}$ & 0.01 & 0.02 & 0.01 & 0.01 & 0.02 & 0.01 & 0.01 & 0.03 \\
\hline 13 & $\mathrm{NH}_{4}^{+}$ & $\mathrm{mg} / \mathrm{l}$ & $<0.01$ & $<0.01$ & $<0.01$ & $<0.01$ & $<0.01$ & $<0.01$ & $<0.01$ & $<0.01$ \\
\hline 14 & $\mathrm{~K}^{+}$ & $\mathrm{mg} / \mathrm{l}$ & 2.5 & 1.95 & 2.34 & 1.17 & 2.50 & 1.17 & 1.99 & 1.36 \\
\hline 15 & $\mathrm{Na}^{+}$ & $\mathrm{mg} / \mathrm{l}$ & 19.25 & 16.12 & 13.59 & 18.88 & 19.25 & 13.59 & 16.96 & 123.39 \\
\hline 16 & $\mathrm{H}_{2} \mathrm{~S}$ & $\mathrm{mg} / \mathrm{l}$ & $<0.01$ & $<0.01$ & $<0.01$ & $<0.01$ & $<0.01$ & $<0.01$ & $<0.01$ & $<0.01$ \\
\hline 17 & $\mathrm{H}_{2} \mathrm{BO}_{3}$ & $\mathrm{mg} / \mathrm{l}$ & $<0.01$ & $<0.01$ & $<0.01$ & $<0.01$ & $<0.01$ & $<0.01$ & $<0.01$ & $<0.01$ \\
\hline 18 & $\mathrm{H}_{2} \mathrm{SiO}_{3}$ & $\mathrm{mg} / \mathrm{l}$ & 7.1 & 7.50 & 6.60 & 7.30 & 7.50 & 6.60 & 7.13 & 14.64 \\
\hline 19 & Total axit on level & mđlg/l & 0.1 & 0.05 & 0.1 & 0.15 & 0.15 & 0.05 & 0.10 & 0.12 \\
\hline 20 & $\begin{array}{l}\text { Total } \\
\text { mineralization level }\end{array}$ & $\mathrm{mg} / \mathrm{l}$ & 75.91 & 67.52 & 65.74 & 70.18 & 75.91 & 65.74 & 69.84 & 320.93 \\
\hline
\end{tabular}

Note: The samples were analyzed at Centre for testing and verifying Building Materials in the Central Part - Names of samples were in column (4) to (7)

Table 3. Analysis results of mud micronutrients-Mineral mud location in Suoi Da village

\begin{tabular}{|c|c|c|c|}
\hline No & Criteria & Unit & Mud material \\
\hline 1 & $\mathrm{pH}$ & & 7.30 \\
\hline 2 & $\mathrm{Hg}$ & & $<0.1$ \\
\hline 3 & $\mathrm{Cd}$ & & 0.2 \\
\hline 4 & $\mathrm{~Pb}$ & & 18.2 \\
\hline 5 & $\mathrm{Cu}$ & & 32.0 \\
\hline 6 & $\mathrm{Zn}$ & $\stackrel{\infty 00}{=}$ & 62.1 \\
\hline 7 & Mo & $\stackrel{\infty 0}{\Xi}$ & 2.0 \\
\hline 8 & $\mathrm{Ni}$ & $\Xi$ & 1.5 \\
\hline 9 & Co & $\stackrel{\Xi}{\Xi}$ & 1.1 \\
\hline 10 & V & 8 & 3.0 \\
\hline 11 & $\mathrm{Be}$ & & 0.2 \\
\hline 12 & As & & 3.2 \\
\hline 13 & $\mathrm{~F}$ & & 0.4 \\
\hline 14 & $\mathrm{Se}$ & & $<0.1$ \\
\hline
\end{tabular}

Note: The samples were analyzed at Nhatrang Institute of Technology Research and Application (Nguyen Duc Thai, 2011)
According to the borehole logs (right on the mud eruption craters), the bottom layer of the clay mud is identified lying at depth of 45 meters. Mud eruption materials, including liquid clay mud of light blue or opaque white color, interspersed with coarse-grained sand and bedrock debris. On the mud vents, there always witnesses pressurized water leaking out, $20 \%$ of which is clay mud. Mud sample analysis shows that clay content of grain size $<0.063 \mathrm{~mm}$ accounts for $58 \%$, clay of grain size $<0.063 \mathrm{~mm}$ makes up $42 \%$. The major mineral components of grains $>0.063-2.5 \mathrm{~mm}$ (equivalent to powder, sand, grit) is as follows: Quartz $=30-40 \%$, feldspar $=30 \%$ and chlorite $=20-30 \%$. Other minerals are mostly $\mathrm{Mg}$-, Ca-carbonate, tourmaline, sericite (Table 5). Thus, the montmorillonite constituent is not large, accounting for only $15-20 \%$ of the total taken samples. 
Vietnam Journal of Earth Sciences 36 (2016) 307-315

Table 4. Analysis results of water micronutrients from mud mound at Suoi Da village, Loi Hai commune

\begin{tabular}{|c|c|c|c|c|}
\hline No. & Analysis criteria & Unit & Content & Vietnamese Standard 6213:2004 \\
\hline 1 & $\operatorname{Iod}\left(\mathrm{I}^{-}\right)$ & $\mathrm{mg} / \mathrm{l}$ & 0.004 & - \\
\hline 2 & Copper $(\mathrm{Cu})$ & $\mathrm{mg} / \mathrm{l}$ & 0.001 & 1.0 \\
\hline 3 & Lead $(\mathrm{Pb})$ & $\mathrm{mg} / \mathrm{l}$ & $<0.001$ & 0.01 \\
\hline 4 & Zinc $(\mathrm{Zn})$ & $\mathrm{mg} / \mathrm{l}$ & 0.051 & - \\
\hline 5 & Cadimi $(\mathrm{Cd})$ & $\mathrm{mg} / \mathrm{l}$ & 0.002 & 0.003 \\
\hline 6 & Mangan (Mn) & $\mathrm{mg} / \mathrm{l}$ & 0.286 & 0.5 \\
\hline 7 & Asen (As) & $\mathrm{mg} / \mathrm{l}$ & 0.010 & 0.01 \\
\hline 8 & Mercury (Hg) & $\mathrm{mg} / \mathrm{l}$ & 0.001 & 0.001 \\
\hline 9 & Florua $\left(\mathrm{F}^{-}\right)$ & $\mathrm{mg} / \mathrm{l}$ & 5.98 & $\begin{array}{l}\text { Recording recommendations on product labels } \\
\text { according to content levels }\end{array}$ \\
\hline 10 & Axit metasilic $\left(\mathrm{H}_{2} \mathrm{SiO}_{3}\right)$ & $\mathrm{mg} / \mathrm{l}$ & 73.05 & \\
\hline
\end{tabular}

Note: The samples were analyzed at Water Resource Service And Counsulting Center (Nguyen Duc Thai, 2011)

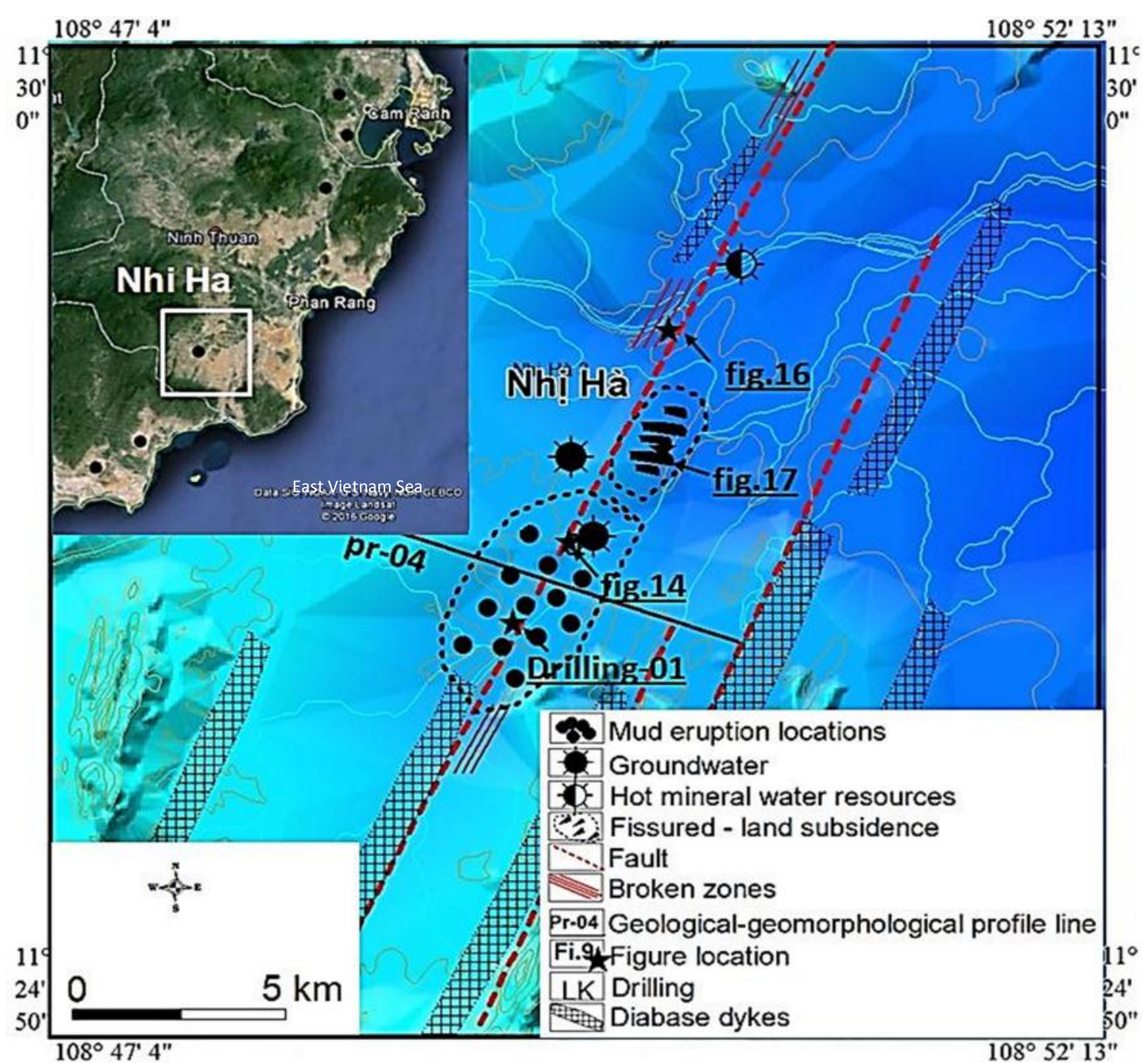

Figure 13. Map of current mud eruption status at Nhi Ha 
Vietnam Journal of Earth Sciences 36 (2016) 307-315

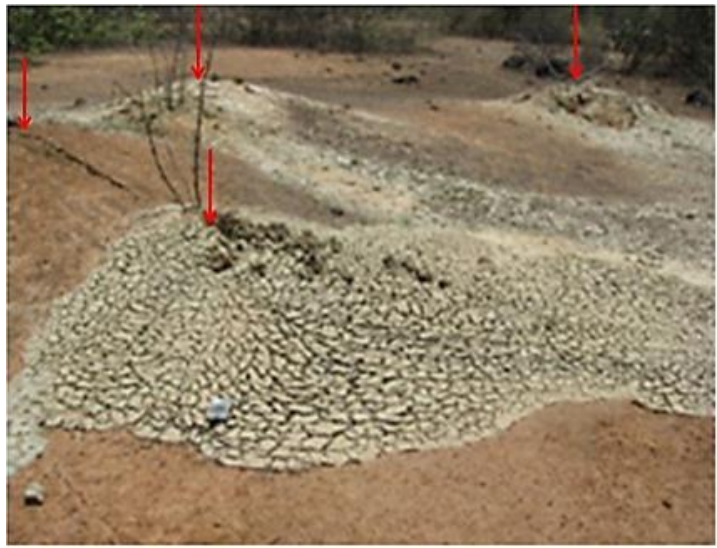

Figure 14. Mud eruption at Nhi $\mathrm{Ha}$

Table 5. Mineral composition at clay level $<0,063 \mathrm{~mm}$ mud eruption location at Nhi Ha, Thuan Nam district

\begin{tabular}{|c|c|c|c|}
\hline \multirow[t]{2}{*}{ No. } & \multirow[t]{2}{*}{ Minerals } & \multicolumn{2}{|c|}{$\begin{array}{c}\text { Mineral composition at clay } \\
\text { level }<0,063 \mathrm{~mm}\end{array}$} \\
\hline & & BNH01 & BNH02 \\
\hline (1) & (2) & (3) & (4) \\
\hline 1 & Montmorilonit & $25-27$ & $20-30$ \\
\hline 2 & Ilit & $10-12$ & 12 \\
\hline 3 & Kaolinit & $13-15$ & $12-15$ \\
\hline 4 & Clorit & 4- 6 & 8 \\
\hline 5 & Felspat & $12-14$ & $10-12$ \\
\hline 6 & Th ch anh & $6-8$ & 6 \\
\hline 7 & Hydroxit s $\mathrm{t}$ (g tit) & $4-6$ & $2-4$ \\
\hline 8 & Canxit $\mathrm{CaCO}_{3}$ & $<10$ & $<10$ \\
\hline 9 & Ankerit $(\mathrm{Mg}, \mathrm{Fe}) \mathrm{CO}_{3}$ & $<7$ & 5 \\
\hline 10 & Fluorit & 5 & 7 \\
\hline
\end{tabular}

Note: The samples were analyzed at Geology Institute - Vietnam Academy of Science and Technology - Column (3) and (4) were names of samples
A geological cross-section (Figure 15) reveals that mud and clay lie in narrow vertical zones with 2-10 meters wide. These are, in fact, dykes belonging to the Phan Rang formation, consisting mainly of biotite-hornblende granodiorite, cross-cutting intrusive magma of the Dinh Quan formation. The dyke-rocks are of calc-alkaline type, with medium alkalinity, and sodium-potassium alkaline type. The dykes and veins are intensely weathered forming a weathering zone of $>10 \mathrm{~m}$ thick. Massive granites are found on the both sides of Dinh Quan formation $(\sigma-\gamma \sigma-\gamma \mathrm{J} 3 d q)$. Bedrocks are cropped out right in the streambed, and in the neighbouring pits, there discover fault zones, tectonic cracks, which are of 0.5-1.0 m in width, in the NE-SW direction $\left(35^{\circ}\right)$, with steep angle; and in those fault zones, numerous sliding surfaces of fault zones and clear tectonic scratches appear (Figure 16). Right beside the mud mounds, at the bottom and sides of the excavated pits, groundwater outflow emerges, and those pits are frequently filled with water, overflowing out of the crater. Besides, about $100 \mathrm{~m}$ to the Northeast of the mud eruption location, a range of pits are detected with cracks and landslides of 100 $\mathrm{m}$ in length and $50 \mathrm{~m}$ wide in the NE-SW and E-W direction (Figure 17). Also about $400 \mathrm{~m}$ to the NE, there outcrops the hot mineral water of Nhi Ha. Thus, the location of mud eruption points, land cracks, faults, outcropped groundwater and the location of hot spring water are both lying in a range in NE$\mathrm{SW}$ direction, more than $5 \mathrm{~km}$ long.

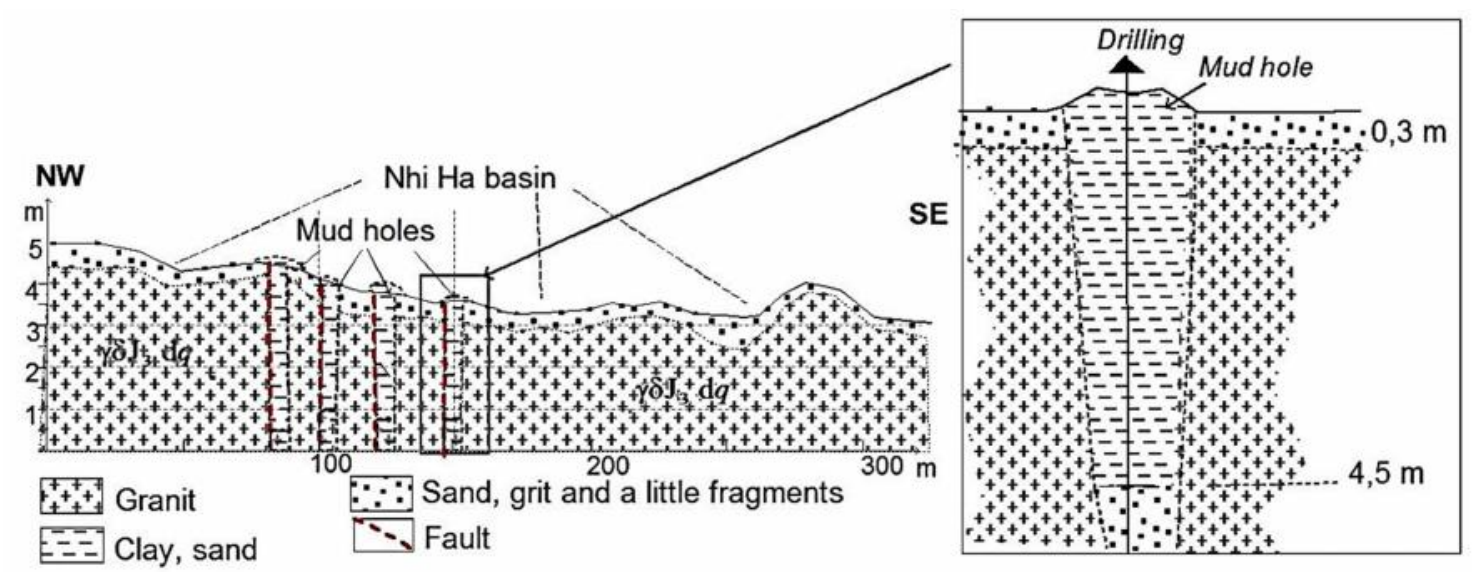

Figure 15. Geological and geomorphological profile at Nhi Ha 
Vietnam Journal of Earth Sciences 38(3), 256-276

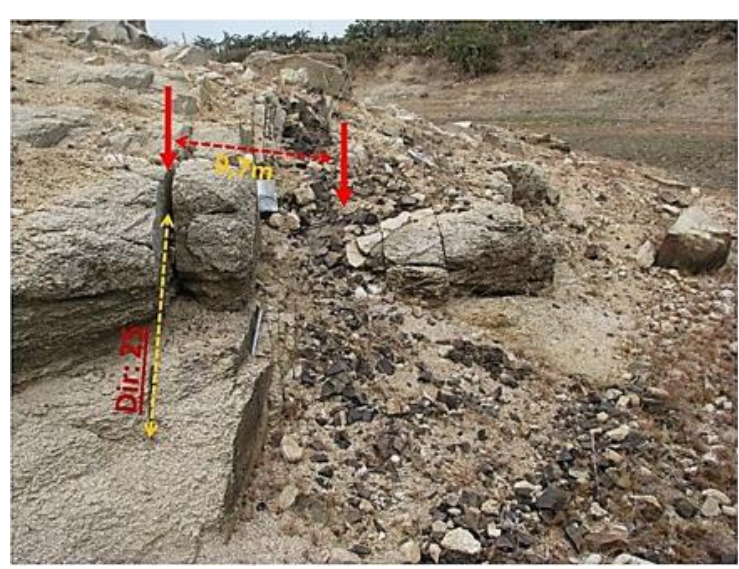

Figure 16. Broken zones in the rock at Nhi Ha 3 village

Mud eruption in Vinh Hao, Vinh Hao commune, Tuy Phong district, Binh Thuan province, at $108^{\circ} 43^{\prime} 11^{\prime \prime} \mathrm{E}, 11^{\circ} 17^{\prime} 52^{\prime \prime} \mathrm{N}$, mud eruption area is in a narrow accumulated lowlying stretch of about $6 \mathrm{~m}$ in thickness. Erupted

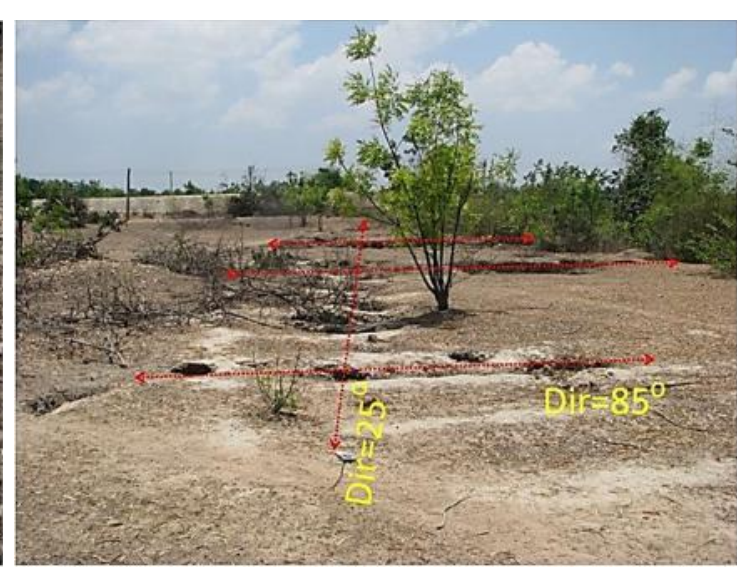

Figure 17. Land cracking and landsliding at Nhi Ha

materials include medium-grained sand, grayish white clay and mud, in which clay mud accounts for $25 \%$. Just inside the mud eruption channel, there appears hot spring water source springing from below (Figure 18).

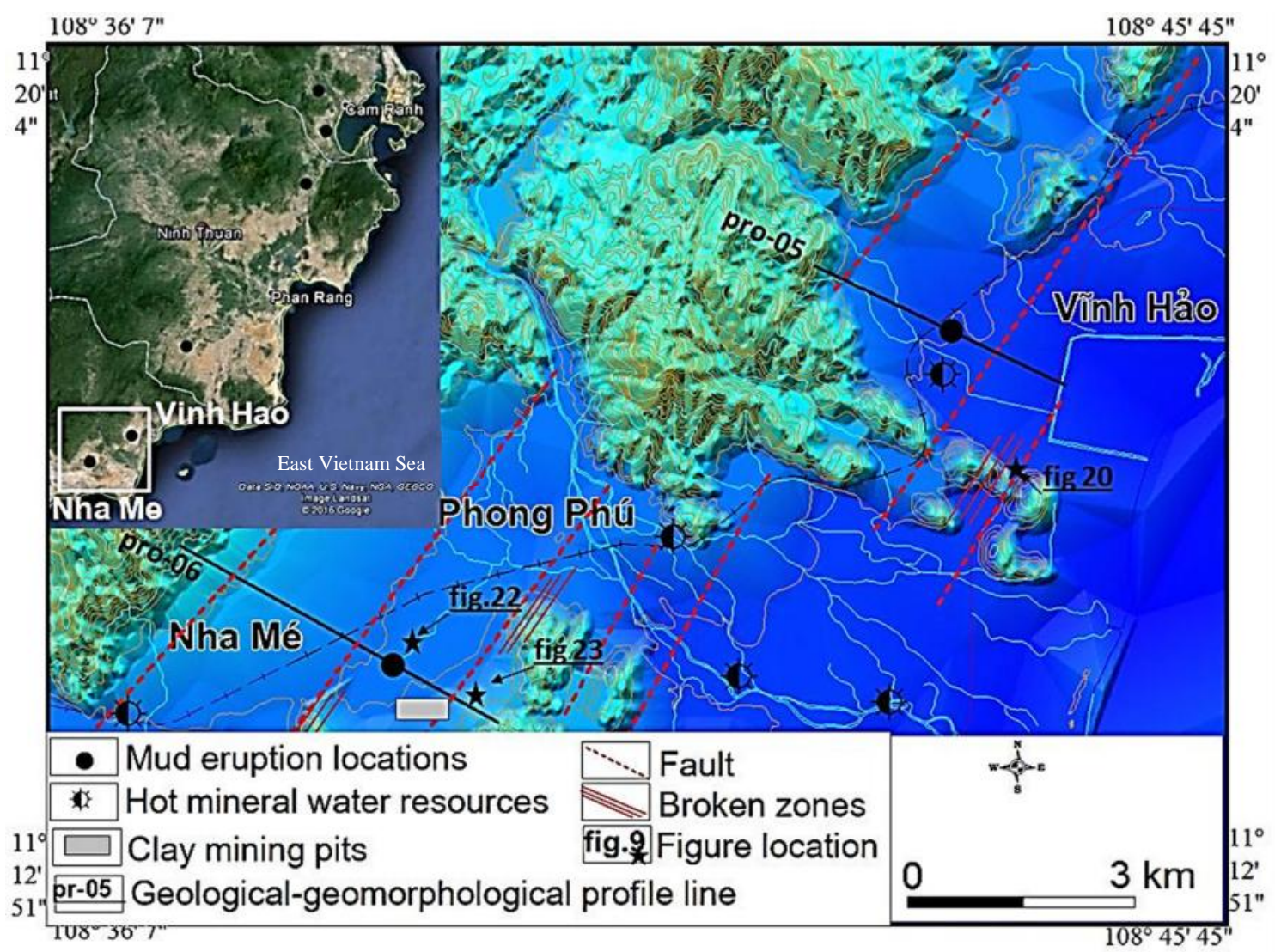

Figure 18. Diagram of current mud eruption status at Vinh Hao and Nha Me 
Geological cross-section of an outcrop at Vinh Hao stream valley and drilled and excavated boreholes includes (Figure 19) the upper layer is loamy soil intercalated with sand and gravel of $0.3 \mathrm{~m}$ in thickness, followed by a layer containing sand and gravel of $1.8 \mathrm{~m}$ thick comprising dacite-rhyolite, then comes the layer of sand, silt, clay, with clay containing mainly montmorillonite, which accounts for $30-60 \%$. This layer is located in a zone of groundwater level fluctuating from 2.0 to $6.5 \mathrm{~m}$; at the bottom there comes a an alluvial sedimentary column consisting of pebbles, gravels and sand, directly covering a incompleted-weathering layer of volcanic rocks of Don Duong formation (K2 đd). At this location, discovered is a tectonic crushed and compressional zone containing muddy clay of 0.5-1.5 $\mathrm{m}$ width spreading in the NE-SW direction (Figure 20). Currently, not only Vinh Hao Mineral Water JSC exploits the mineral water bottling, but some travel agencies in Binh Thuan province have also exploited the water and built mineral mud and hot spring water bath tubs for healing purposes within the area.

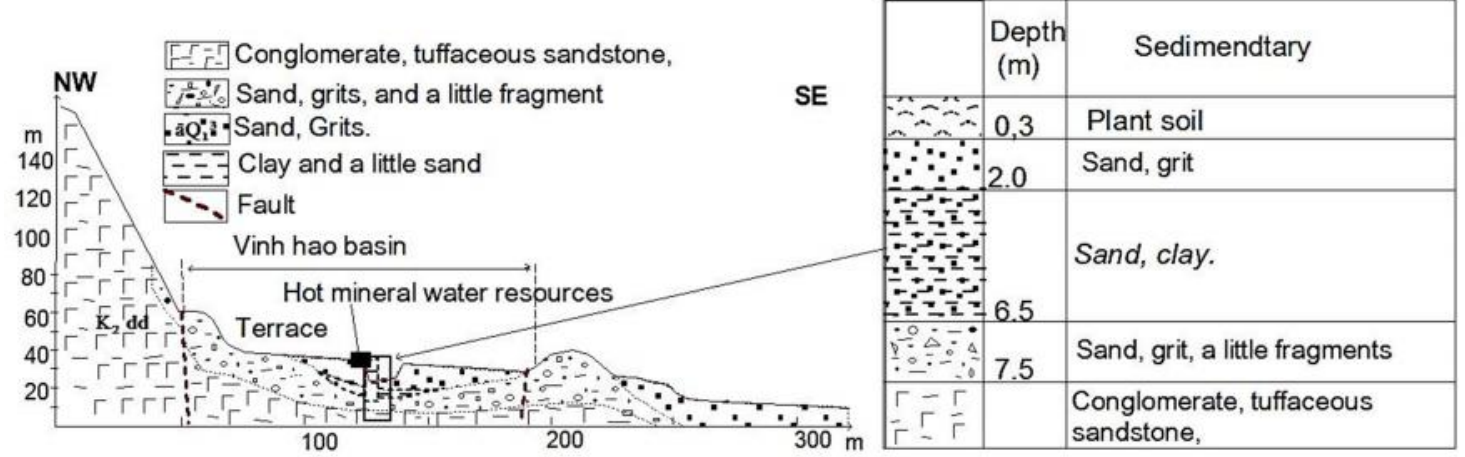

Figure 19. Geological and geomorphological sections at Vinh Hao

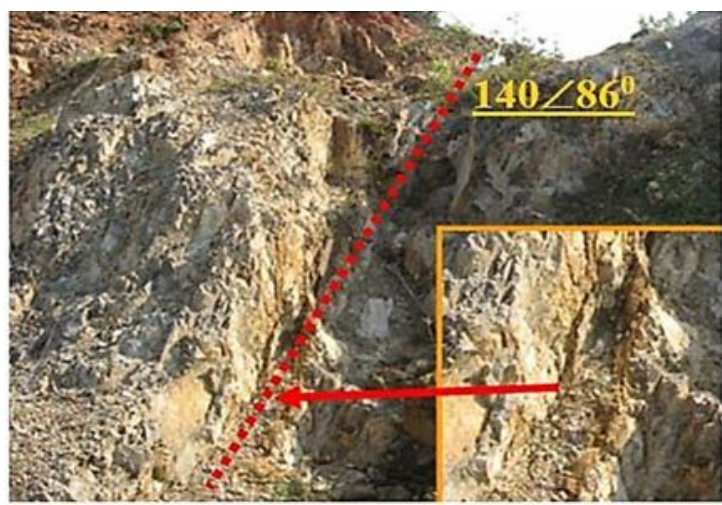

Figure 20. Broken zones in the rock at Vinh Hao

Mud eruption in Nha Me, Tuy Thinh village, Tuy Phong District, Binh Thuan Province, at $108^{\circ} 38^{\prime} 51^{\prime \prime} \mathrm{E}, 11^{\circ} 14^{\prime} 54^{\prime \prime} \mathrm{N}$ forms a mud mound of about 7 meters in circumference, and $0.7 \mathrm{~m}$ in height (Figure 22). The mud mound lies on a valley plain surface in the middle of a mountain range (Nha Me valley), spreading in the NE-SW direction, of about $1.5-2 \mathrm{~km}$ in width, with the two valley sides controlled by walls, hillsides, mountainsides with a large slope $\left(50-70^{\circ}\right)$. Components of erupting mud include fine-grained sand, bluish gray clay and mud paste. The clay is bentonite, accounting for about 60\% (Ho Vuong Binh et al., 1990). A geological cross-section (Figure 21) of boreholes and mined pits shows that the clay mud component contains montmorillonite, ranging from $30-60 \%$ in the zone of groundwater level fluctuating from 1.8-9.5 m. This bed is covered by river sediments (pebbles, gravels and sand) and directly lies on the incomplete-weathering volcanic rocks of Don Duong formation (K2 đd). About 100 meters to the west from the mud eruption site, there appears crushed, broken rock zone, 
trending in the NE-SW direction (Figure 23). Thinh, Long Song River and Chau Cat, of the In the NE and SW sides, there revealed hot bicarbonate water type (Vo Cong Nghiep, mineral water sources, which are Nha Me, Tuy 1988).

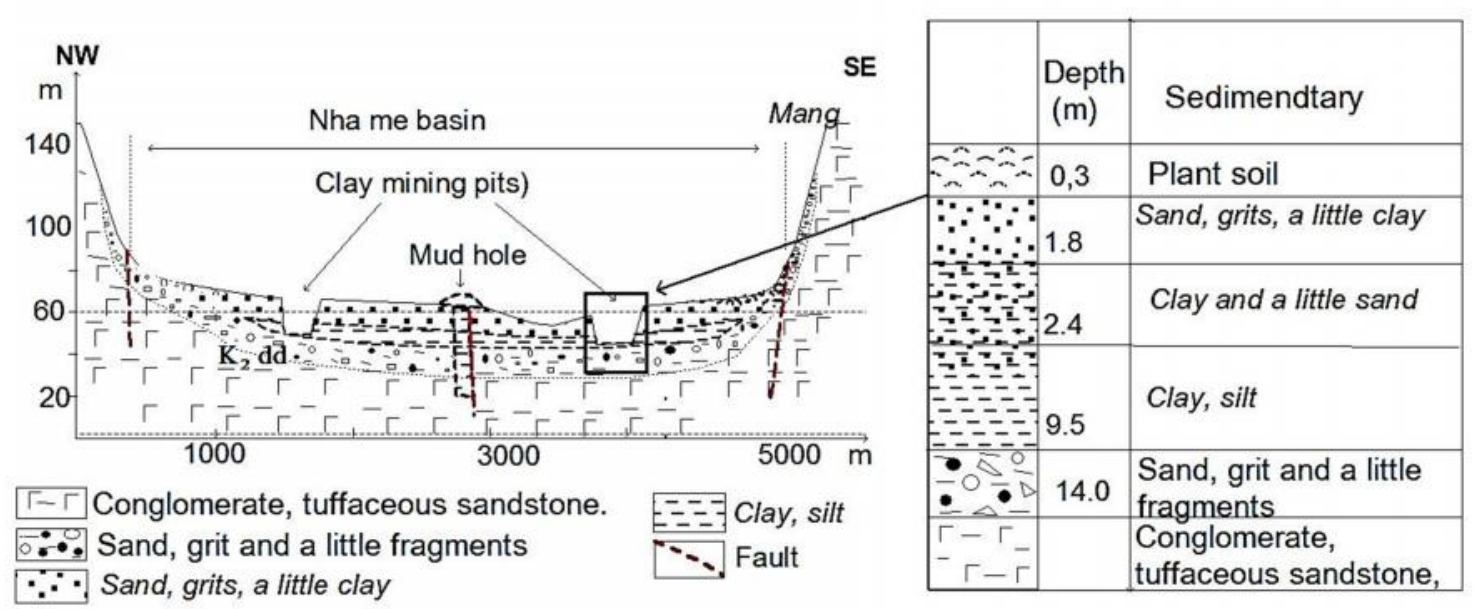

Figure 21. Geological and geomorphological sections at Nha Me

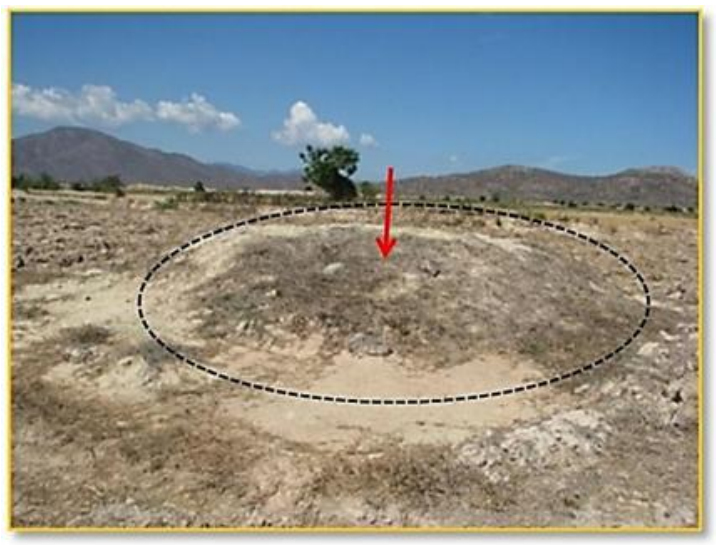

Figure 22. Mud eruption Mound at Nha Me

Thus: Most of the mud eruption locations (except for the mud eruption location in $\mathrm{Ta}$ Luong which lies within the range of NW-SE direction) are lying in a wide range of 20-100 $\mathrm{m}$ wide, but up to $200 \mathrm{~m}$ in $\mathrm{Nha} \mathrm{Me}$, in the direction of NE-SW (20-300). Within this range, there not only exist mud eruption sites but also sources of hot spring water, pressurized underground water, landslide cracks and tectonic crushed zones, which are also common. The clay mud materials are located in a depth of 4-18 m, with a thickness of approximately 1-3 m, and contain alkaline-

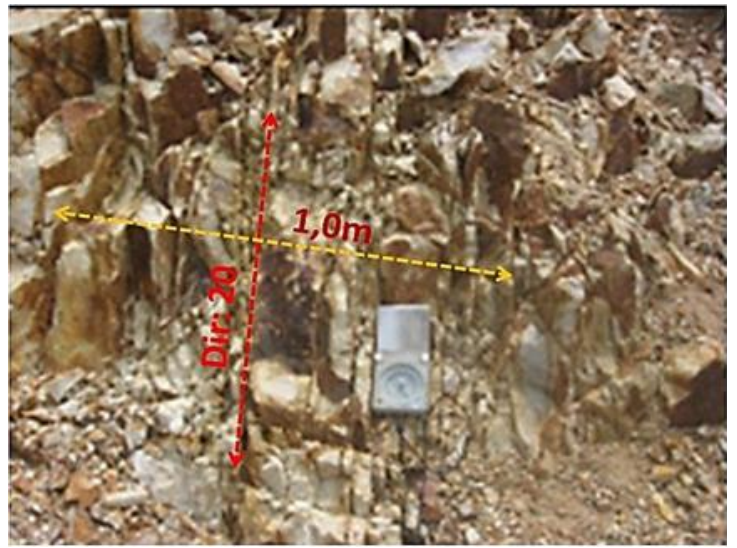

Figure 23. Broken zones in the rock at Nha Me

rich montmorillonite. In the area of Ta Luong, Cam Thinh Dong, Suoi Da village and Nhi $\mathrm{Ha}$, the clay mud materials with weathered origin, are formed in the weathering zone of bedrock types containing alkaline-rich mineral components in the semi-arid climate and in the tectonic subsidence low-land areas. In the area of Nha Me and Vinh Hao, clay mud is re-deposited, which is formed and directly hauled into the sedimentary basins on site, forming clay lenses as the result.

At present, several mud sites have been exploited for bentonite clay in the purposes of 
B.V. Thom, et al./Vietnam Journal of Earth Sciences 38 (2016)

drilling fluids, nano- bentonite clay, skin-care mud in Nha Me (http://www.mhc.vn/) and healing mud bath (Cam Thinh Dong, Vinh Hao). In addition to these advantages, the mud eruption often causes losses from agricultural land and endangers people, especially in the areas of Suoi Da and Nhi Ha villages. It forms a large abandoned area, which is uncultivable. Some cattle fell into the pits, hence the local government shall install warning signboards and fences around.

\subsection{Factors relating to mud eruption}

\subsubsection{Climate factor}

The chemical analysis reveals that the erupted mud contains alkaline bentonite. According to Ho Vuong Binh et al. (1990), among the conditions for alkaline bentonite clay formation, the climate is a significant factor, because the clay can only be formed in the arid climate region with great groundwater level fluctuation. The study area is located in the coastal region from Cam Ranh to Binh Thuan, which has satisfied this condition as the climate, here is of drought and dry zone with short rainy season and longer dry and drought season. The annual average evaporation is much greater than the annual rainfall (Pham Van An et al., 1990).

\subsubsection{Geographical and geomorphological factors}

The coastal region from Cam Ranh to Binh Thuan is composed of four main types of terrain: (1) mountainous, invasive - denuded hills, distributed in the West, being cut by a system of rivers and streams into long strips in the NE-SW and N-S direction; in addition, to the North of Thuan Bac and the South of Thuan Nam, two mountains ranges align in nearly sub-parallel direction trending close to the sea; (2) The denuded hill delta forming the NE-SW direction range: (3) The type of transitioning terrain between mountains and plains; IV) The coastal accumulated delta with river, sea and wind origins (Le Duc An, 1990; Uong Dinh Khanh, 2004).

The notable point is the development of several local basin types distributed along the domain boundary between the hills, mountains and the plains. Since bentonite clay type has a very high degree of flexibility, those basins become favorable conditions for keeping alkaline clay minerals from being washed out. Some of the low-lying terrains are mentioned as follows:

Loi Hai is a trough-formed basin running along the NE-SW direction with the two sides being fenced by mountain ranges, large dipping slopes, about $10 \mathrm{~km}$ long, nearly $1 \mathrm{~km}$ wide; the bottom is covered by a Quaternary accumulated layer having the thickness of approximately $2-10 \mathrm{~m}$ directly on the weathered bedrock. In the basin appear two mud eruption sites, Suoi Da and Cam Thinh Dong villages, and reveal a source of hot mineral water of $\mathrm{Ba}$ Ngoi. Nhi Ha basin extending along the NESW direction with a width of about $3.7 \mathrm{~km}$, and a length of $8-10 \mathrm{~km}$. Whose bottom is overlain by a very thin accumulated Quaternary layer of 0 to $0.5 \mathrm{~m}$ thick, being constrained on the two sides by two hilly ranges running in the same direction. Inside the valley, the undulating hilly plains exist with the ledges of bedrocks emerging at $1-5 \mathrm{~m}$ high; many locations in the streambed are found with bedrocks such as granite intrusive rocks. In fact, those low-lying strips of land are located in coincidence with the dyke veins of the $\mathrm{Cu}$ Mong and Phan Rang formations. Inside this basin, there are mud eruptions in Nhi Ha and the source of hot mineral water. Vinh Hao basin, in coincidence with Vinh Hao River Valley in the NE-SW direction, is of $300 \mathrm{~m}$ in width, $500 \mathrm{~m}$ in length, the center of which is Quaternary alluvial accumulated layer of a thickness of $10 \mathrm{~m}$. The basin is constrained by high mountain ranges to the North, and the highly emerging ledges or accumulated-denuded seabed with 1-2 $\mathrm{m}$ in height. 
Situated in the valley is the mud eruption location and hot mineral water source of Vinh Hao. Nha Me basin is the biggest regional graben-formed of a basin in the NE-SW direction, with the two sides of high mountain and hill, with nearly $10 \mathrm{~km}$ in length and 1 to 2.5 $\mathrm{km}$ in width, the central part of which is the accumulated Quaternary of 15-20 m thick, containing bentonite clay set of $5-10 \mathrm{~m}$ in thickness. Inside the trough, there also reveal a mud eruption location and sources of hot mineral water (sources of Nha Me, Tuy Thinh and Chau Cat).

\subsubsection{Hydro-geological factor}

Cam Ranh- Binh Thuan region has the fairly typical hydrological conditions characterized by semi-arid climate, in which the dry season is longer than wet season, therefore, surface water is exhausted in dry season (Pham Van Nam and others, 1988). On the other hand, this area is structured by intrusive magmatic rocks, making groundwater scarce in volume, and the dry season almost has no water in the aquifers but along the tectonic fault zones. Yet, groundwater in these tectonic fault zones is relatively plentiful and the type of pressurized water: in the research area, they concentrate to form zones with different directions. Among them, there is considerably large zone stretching in the NE-SW direction, inside which there develop the abovementioned mud eruption locations (Cam Thinh Dong, Loi Hai, Nhi Ha, Vinh Hao and $\mathrm{Nha} \mathrm{Me}$ ) and strongly tectonic broken and smashed rocks. Along the fault zone, there also reveal sources of groundwater in the mud erupting craters and on the walls of pits. The actual observations of the flow direction of revealed locations and the geomorphology cross-section of Loi Hai and Nhi Ha areas, and the hydro-geological map (P. Stepanek, Ho Trong Ty, 1986) show that the groundwater tends to flow from NW (mountains, hills) to SE (the delta), then converges along the broken, smashed zones in the NE-SW direction. Whereas, outside of those broken, smashed zones, the groundwater is very limited even for the $100 \mathrm{~m}$ deep wells. Thus, groundwater in broken zones is one of the significant conditions not only for creating pressure to push the mud and sand materials to go upward onto the terrain surface, but also for facilitating the processes of strong chemical weathering at depth. The results of the water analysis (Ho Vuong Binh and others, 1990), present that soda groundwater is popular in Cam Ranh-Binh Thuan with the total mineralization of $0.5-5 \mathrm{~g} / \mathrm{l}$. Besides, along this strip there reveal sources of hot mineral water as mentioned above, coming up from the depth to be distributed near the mud eruption locations, belonging to the rich alkaline bicarbonate mineral water type (Vo Industrial, 1998), participating and supplementing to the groundwater zone. This is an important condition to the process of chemical weathering and hydrolysis of the alkali-rich rocks to form a weathering zone containing alkaline montmorilonit minerals.

\subsubsection{Geological factor}

The mud eruption sites are mostly in geological formations (Figure 24) such as the La Nga $\left(J_{2} \ln \right)$, Bao Loc Pass $\left(J_{3} d b l\right)$, Nha Trang $\left(\mathrm{K}_{2} \mathrm{nt}\right)$ formations, and intrusive magmatic formations include Dinh Quan formation (6$\left.\gamma^{\sigma}-\gamma \mathrm{J} 3 \mathrm{dq}\right)$, Deo Ca $\left(\gamma \sigma-\gamma-\gamma \xi \mathrm{K}\right.$ đc), Ca Na $\left(\gamma \mathrm{K}_{2}\right.$ $\mathrm{cn}$ ), Phan Rang formation ( $\gamma \pi \mathrm{E}$ đq) with the chemical compositions containing alkaline elements, including the volcanic rocks of Don Duong formation, intrusions of the $\mathrm{Ca} \mathrm{Na}$ and Phan Rang complexes that contain high concentrations of alkali (Na, K) (Nguyen Duc Thang, 1988; P. Stepanek , Ho Trong Ty, 1986). This is the prime geological criterion that forms alkaline clay minerals, in which alkaline montmorillonite has high-swelling properties. This is one of the important factors involved in the process of pushing mud material up onto the surface. 
B.V. Thom, et al./Vietnam Journal of Earth Sciences 38 (2016)

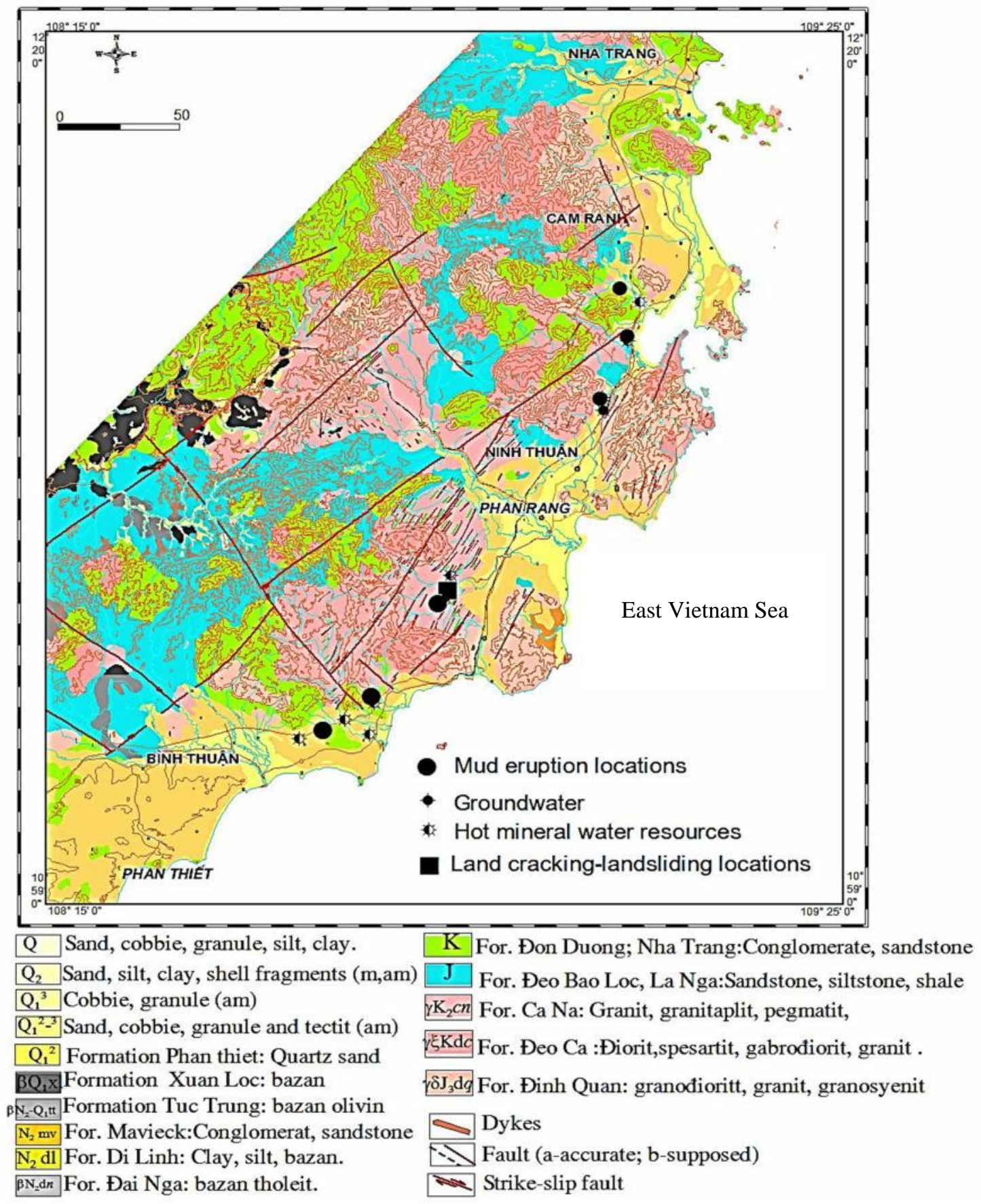

Figure 24. Geological map at Ninh Thuan - Binh Thuan

\subsubsection{Tectonic factor}

On the map of mud eruption status, it is clearly shown that the mud eruption locations are allocated into a large strip in the NE-SW direction. At each location, it is possible to determine geological signs of the existence of tectonic fault zones. The measurements for geo-electricity in Loi Hai clearly identified faults in the NE-SW direction. Also, at some 
mud eruption sites (Nhi Ha area as the most obvious case), there is a range of coinciding dyke-veins cutting across the fractures and faults in the NE-SW direction within intrusive rocks in the formations of Dinh Quan and Deo $\mathrm{Ca}$. Particularly, in the range of mud eruption, shown are a variety of signs of active tectonic faults, which are the revealing sources of hot mineral water springing from the depth upward (sources of Ba Ngoi, Nhi Ha, Vinh Hao; Tuy Thinh; Nha Me; Chau Cat, Long Song River), the emergence of pressurized groundwater (Loi Hai, Nhi Ha) and the appearance of a long slump cracked strip of 100 meters in length in the NE-SW direction in Nhi Ha. However, the faults here are of much smaller size than the large-scale faults that may cause earthquakes far from the research area (> 60$100 \mathrm{~km}$ ), such as the fault zones of Thuan Hai-Minh Hai, Tuy Hoa - Cu Chi, Ba Song, Nha Trang-Tanh Linh (Pham Van Thuc and others, 2004; Le Duy Bach and others, 2007; Cao Dinh Trieu, 2006; Tran Van Thang and others, 2005; Pham Van Hung, 1996, 2001; Cao Dinh Trieu, Pham Huy Long and others, 2013), or may create a great air pressure and push the materials upward (Phung Van Phach, Nguyen Trong Yem and others, 1993) or make them emerge to form mud diapirs, being shown in the seismic cross-section in the East Sea (Phan Trong Trinh, 2012) or in many parts around the world. The large faults are the main cause of mud eruption as in the Southeast of Spain (T. Medialdea, Samoza, 2003), East of China (P. Yin, S. Bern et al, 2003), South of Taiwan (Quo-Cheng Sung and others, 2010), and Indonesia (A. Mazzini, A. Nermoen,... 2009).

Thus, the major NE-SW tectonic fault zones not only influence the formation of mud erupting materials, but also have major direct impacts on creating channels for mud to eject upward.

\section{Discussion and conclusions}

\subsection{Distribution rule of mud eruption}

Synthesizing the above-mentioned facts, clearly all the above mud eruption sites are related to a fault zone or a tectonic zone basing on the following pieces of evidence:

The distribution of all mud eruption sites forms a linear strip in the northeast southwesterly direction from Cam Ranh Ninh Thuan - Binh Thuan, excepting for Ta Luong in northwest-southeast direction, and all the locations are in narrow graben-like basins or semi-enclosed basins trending in northeast - southwesterly direction, reflecting tectonic extension - subsidence activities.

The expression for a series of deep hot mineral water sources at the surface, such as, at Ba Ngoi, Loi Hai, Nhi Ha, Vinh Hao, Tuy Thinh, Nha Me, Chau Cat, Long Song River and pressurized groundwater spring (Loi Hai, Nhi Ha) are a clear demonstration of the deep faulting links.

At most of the mud eruption sites and adjacent areas, crushed zones are found in which the crack systems trending mainly in the NE$\mathrm{SW}$ and S-N directions. The slip planes and tectonic scratches, shears zones are also in NE- SW direction.

There is the presence of fracturing landslides expanding in NE- SW and S-N direction right at mud eruption location of Nhi Ha.

At Nhi $\mathrm{Ha}$, the mud eruption occurs through a series of NE-SW igneous dykes.

The geophysical measurements at Suoi Da mud eruption determine the existence of fault crossing.

However, there is currently not enough evidence to determine whether these faults developed continuously or discontinuously and whether they are still active in the current period. Further study should be needed.

\subsection{Mechanism and geodynamics of mud eruption}

Combining the above results, the mechanism of the mud eruption process in the Cam Ranh - Binh Thuan area maybe commented as follows:

The phenomenon of mud eruption is due to the combine effect of internal and external factors, including geo-lithological (rock con- 
taining alkaline minerals), terrain (basins), hydrological (pressurized groundwater), climate (dry and hot climate), and tectonic (subsidence zone, tectonic subsidence zone) factors.

With regards to the origin of erupted mud material: clay mud is not deep level-derived (in the deep lithosphere layer), but is from shallow part in the crust. The mud contains alkaline bentonite clay formed in a tectonic subsidence zone. The origin of this clay mud is formed by chemical weathering and hydrolysis processes of alkali-rich minerals or re-sedimentation process in a dry and hot climate environment with a high-level groundwater fluctuation. The clay mud material resides between the depth from 4 to 15 meter and is covered by Quaternary unconsolidated sedimentary layers.

In terms of the mud eruption process: Initially, as the materials approached water, a part of remaining bentonite clay, having not been water-saturated was expanded, increasing the volume and creating pushing pressure; however, this was not the main cause since the real proportion of bentonite clay was low, just $20-30 \%$, and the fact was that the clay was normally in groundwater, so it almost has reached the saturation.

Meanwhile, the groundwater is pressurized in a tectonic subsidence zone with a relatively strong underground flow that can flow strongly in both horizontal and vertical directions and creates a pressure pushing mud from a deep level up to the surface along a tectonic fractured or fault zone. When it comes to the ground, at the edges of mud mounds, clay becomes dehydrated and dried creating mud mounds with heights of from 0.3 to $1 \mathrm{~m}$, while at the center of the vent edge, mud continues to erupt to the surface with different volumes since the groundwater regularly follows the cracks overflowing on the terrain surface in dry season, mud continues to erupt but not strongly, whereas in wet season, supplemented groundwater with clay mud material erupts more strongly than that in dry season, which creates the lines of mud in tens of meters long around the vent edge in many places.

Thus, tectonic factors are significant, indirectly impact on creating a tectonic subsidence zone, which makes the weathering process deeper and environment for precipitation of alkaline minerals, the most leachable minerals. The subsidence zone also appears to be a location where groundwater collection and water flowing channel for both deep and horizontal direction; the channels lead mineral water from deep level to supplying soda components, facilitating the process of chemical weathering of rocks rich in alkali that creates the bentonite clay. The tectonic activity is also a direct factor, creating fractures as channels for the mud flow together with groundwater from the depth to the surface.

\section{Acknowledgements}

This Article is a part of research results of the basic research project funded by the Vietnam Academy of Science and Technology under grant VAST05.03/14-15. The author would like to thank colleagues of the Division for Water Resources Planning and Investigation for the Central Region of Vietnam, Department of Actual Geodynamics, Mineral Department - Institute of Geological Sciences for collaborating and helping in the process of completing this work.

\section{References}

Cao Dinh Trieu, 2006. Characteristics of Earthquake Activities of Central Southern and Southern Sea. Journal of Geology, Range A, 293(3-4), Hanoi.

Cao Dinh Trieu, et al., 2013. Modern geodynamics in Vietnamese territory. Natural Sciences and Technology Publishing House, Hanoi, 242.

Ho Vuong Binh, et al., 1990. Research report on evaluation of prospects and possibility of using alkaline bentonite at Thuan Hai. Archived at the Center for Information \& Archives of Geology, Hanoi.

Le Duc An, 1990. Geomorphological and neotectonic features of Thuan Hai area. Geological Science and Technique 
Vietnam Journal of Earth Sciences 38(3), 256-276

Information, (1-2), 5-25, Hanoi.

Le Duy Bach, et al., 2007. Tectonic features Pliocene Quaternary at Southeast continental shelf of Vietnam. Journal of Sciences of the Earth, 29(3), 218-227, Hanoi.

Mazzini. A, A. Nermoen, M. Krotkiewski, Y. Podladchikov, S. Planke, H. Svensen, 2009. Strike-slip faulting as a trigger mechanism for overpressure release through piercement structures. Implications for the Lusi mud eruption, Indonesia. Marine and Petroleum Geology, doi:10.1016/j.marpetgeo.2009.03.001

Medialdea. T, et al., 2003. Tectonics and mud eruption development in the Gulf of Cadiz. Marine Geology, 261(14), 48-63.

Nguyen Duc Thai, et al., 2011. Report on survey results of land crack and mud appearance locations at Suoi Da village, Loi Hai commune, Thuan Bac district, Ninh Thuan province. Archived at Division for Water Resources Planning and Investigation for the Central Region of Vietnam.

Nguyen Duc Thang (chief author) et al., 1988. Report on surveying and mapping of Geology and Minerals in Phan Rang-Nha Trang area at 1:200,000 scale. Archived at the Center for Information \& Archives of Geology, Hanoi.

Nguyen Hong Phuong, 2004. Map of earthquake dangerous rate in Vietnam and the East Sea. Journal of Sciences of the Earth, 26(2), 97-111, Hanoi.

Pham Van An, et al., 1990. Features of weathering crust at dry hot area Thuan Hai and origin of alkaline bentonite clay. Geological Science and Technique Information, (1-2), 72 79, Hanoi.

Pham Van Hung, 2000. Determining kinematic properties of cracks by analyzing tectonic cracks in the South Central region, Journal of Sciences of the Earth, 29(2), 113119, (in Vietnamese).

Pham Van Hung, 2001. Quaternary - modern operational features of tectonic fault at the East edge of Kon Tum massif. Journal of Geology, 267, 43-49, Hanoi.

Pham Van Nam, et al., 1988. Report on hydrogeologicalengineering geological Mapping at 1:200,000 scale in Phan
Rang-Nha Trang region. Archived at Division for Water Resources Planning and Investigation for the Central Region of Vietnam, Nha Trang.

Phan Trong Trinh, 2012. Recent tectonics and modern geodynamics in Vietnam's Sea and adjacent zones. Natural Sciences and Technology Publishing House, Hanoi, 331p.

Pham Van Thuc, et al., 2004. Seismic zoning of the East Sea and coastal area in Vietnam. Journal of Geology, Range A, 285(11-12), Hanoi.

Phung Van Phach, et al., 1996. Some research results of gases ash eruption phenomenon at Pleiku Highland in 1993. Geological Resources, 1, Science and Technique Publishing House, 396-405.

Quo-Cheng Sung, Hung-Cheng Chang, HSing-Chang Liu, YenChieh Chen, 2010. Mud eruption along the chihan fault in Southwestern Taiwan Arelease bend model. Geomorphology, 118, 188-198.

Tran Van Thang, et al., 2006. Tectonic development characteristics of Da Lat zone and adjacent zone in late Mezozoi-Kainozoi. Journal of Sciences of the Earth, 28(2), 140-149, (in Vietnamese)..

Stepanek P., Ho Trong Ty, 1986. Report on mineral geological mapping at Phan Rang-Cam Ranh at 1:50,000 scale. Archived at the Center for Information \& Archives of Geology, Hanoi.

Vo Cong Nghiep, et al., 1998. List of hot water and minerals resources in Vietnam. Ministry of Industry, General Department of Geology and Minerals of Vietnam, Hanoi. $308 \mathrm{p}$.

Uong Dinh Khanh, 2004. Geomorphological characteristics of the hilly areas Ninh Thuan - Binh Thuan. Doctorate thesis, archived at National Library, Hanoi.

Yin. P, S. Bern, P. Vagner, B. Loubrieu, Z. Liu, 2003. Mud eruption at the shelf margin of the East China Sea. Marine Geology, 194(3-4), 135-149.

http://www.mhc.vn/. Minh Ha Bentonite Minerals JSC. 